\title{
Intraday Liquidity Provision by Trader Types in a Limit Order Market: Evidence from Taiwan Index Futures
}

\author{
By \\ Junamo Chiu, Huimin Chung, George H. K. Wang**
}

Second version, March 9, 2012

Keywords: Liquidity Provision, Limit Order Market, Institutional Traders, Individual Traders

\footnotetext{
**Junmao Chiu is at Graduate Institute of Finance, National Chiao Tung University, Taiwan. Huimin Chung is a Professor of Finance, Graduate Institute of Finance, National Chiao Tung University; Taiwan. George H. K. Wang is the Research Professor of Finance, School of Management, George Mason University, Fairfax, VA, 22030. A part of this work was done when Junmao Chiu was a visiting scholar in the Finance area, School of Management, George Mason University, Fairfax, VA 22030. E-mail: gwang2@gmu.edu.
} 


\title{
Intraday Liquidity Provisions by Trader Types in a Limit Order Market: Evidence from Taiwan Index Futures
}

\begin{abstract}
This paper examines the dynamic liquidity provision process by institutional and individual traders in the Taiwan index futures market, which is a pure limit order market. This paper provides empirical evidence in a natural market setting for the period January 2007-December 2008. Several interesting empirical results are obtained. First, institutional traders use relatively more limit orders than market orders. However, foreign institution traders use relatively high percentage of market orders in the early trading session and switch to more limit orders for the rest of the day, except close to the end of the trading day. Liquidity provision by individual traders is just the reverse of that by foreign institutional traders during the trading day. Second, net limit order submissions by both institutional and individual traders have positive relations with one-period lagged transitory volatility and negative relationship with informational volatility. Third, the net limit order submissions by institutional traders have positive relationship with one period lagged spread; fourth, both the state of limit order book and order size have significant influence on all types of traders' strategy on submission of limit order versus market order during the intraday trading session.
\end{abstract}




\section{Intraday Liquidity Provision by Trader Types in a Limit Order Market:}

\section{Evidence from Taiwan Index Futures}

\section{Introduction}

Electronic limit order market has become one of the major trading venues in equity, futures and option exchanges around the world. There are no designated market makers in these markets. As such, limit orders supply liquidity whereas market orders consume liquidity in these markets. Thus, liquidity arises endogenously from the orders submitted by market participants in the exchanges. Since liquidity is considered one of the major performance measurements for exchanges, researchers, exchange officials, and investors have strong interests in understanding the factors affecting the limit order submission rate by different types of traders under different market conditions.

Previous literature on limit order trading strategy can be classified into two strands: theoretical models and empirical analysis. Earlier theoretical models assume that informed traders who trade on short-lived, private information are impatient and would place market orders, whereas uninformed traders who use limit orders have to await execution (see Glosten, 1994; Seppi, 1997). Later theoretical models (see Chakravarty and Holden, 1995; Harris, 1998; Kaniel and Liu, 2006 and others) relax this restrictive assumption. They suggest informed traders use both limited orders and market orders. In general, they show that the time horizon of private information is positively related to the probability of using limit order by informed traders.

Using experimental asset market, Bloomfield, O'Hara and Saar (2005) investigate empirically the evolution of liquidity provision by trader type in a pure limit order market under an experimental market setting. They find that informed traders consume liquidity earlier in the 
trading day and gradually become liquidity providers as they increasingly place more limit orders as the trading day progresses. In contrast, liquidity traders use the reverse of trading strategies of informed traders using during the trading process. They also document that informed traders use relatively more limit orders. These interesting experimental results present a challenge to the assumptions of the theoretical models on the order choice of informed traders in a limit order market.

Goettler, Parlour and Rajan (2005) study the dynamics of order choices in a limit order market under asymmetric information. They suggest that the volatility of changes in the fundamental value of an asset affects agents acquiring information about the asset, which in turn affects the choice of order type of informed traders and market outcomes. ${ }^{1}$ Keim and Madhavan (1995) present empirical evidence on the order choices of institutional traders. They document that informed traders with short-lived information tend to use market orders, while informed traders with long horizon information (e.g., value traders) are more likely to use limit orders.

On the empirical literature side, Biais, Hillion and Spatt (1995) examine the relationship between the limit order book and the order flow in the Paris Bourse. They find that the conditional probability of submitting limit (market) orders by investors is higher when the spread is wide (tight). Chung, Van Ness and Van Ness (1999) also show that traders place more limit orders when the intraday spread is wide in New York Stock Exchange (NYSE).

Ahn, Bae and Chan (2001) examine the role of limit orders in providing liquidity in the Stock Exchange of Hong Kong (SEHK), a pure limit order market. They find that one lagged

\footnotetext{
1 Their results are obtained numerically from their theoretical model because they cannot obtain a closed form solution when the relevant frictions of a limit order market are incorporated in the model. The relevant frictions of a limit order market are discrete price staggered trader arrivals and asymmetric information (sees Goetter et al., 2009, page 68). For other theoretical models on the dynamics of order choice in limit-order markets, see Rosu (2009) and Parlour and Seppi (2008).
} 
period transitory volatility is the major determinant of market depth (due to the submission of limit orders), and rise in market depth is followed by a decrease in volatility. ${ }^{2}$ Volatility also determines the changing mix of market and limit orders.

Bae, Jang and Park (2003) examine the trader's choice between limit and market orders using a sample from the NYSE SuperDot. They find that the order size, spread, and expected transitory volatility are positively related with the trader order choice. Using data from the Moscow Interbank Currency Exchange, Menkhoff, Osler and Schmeling (2010) investigate the use of aggressive-price limit orders by informed and uninformed traders in an ordered logit regression framework. They show that informed traders are more sensitive to changes in the spread, volatility, and market depth than uninformed traders in a pure limit market. However, to the best of our knowledge, there is no previous literature on investigating the difference in market impact on order submission strategy by individual day traders, individual non-day traders and foreign institution traders in the real world market settings.

The major purposes of our papers are:

First, we document the intraday liquidity provision by trader types in a pure limit order market by using the actual intraday data to document the liquidity provision by individual traders (day and non-day traders) and institutional traders (foreign institutional firms and proprietary futures firm traders) in the Taiwan index futures market for the period January 2007-December $2008 .^{3}$

\footnotetext{
${ }^{2}$ Ahn et al. (2001) did not accurately estimate transitory volatility. They use realized volatility to approximate transitory volatility.

${ }^{3}$ In financial literature, it is generally agreed that institutional traders are informed traders because they collect and analyze market information more quickly than uninformed traders in index futures markets. On the other hand, individual investors often follow their observed market prices pattern as their major inputs for their trading decision.
} 
Second, we examine the impact of various market conditions (i.e., one-period lagged transitory and informational volatility, one-period lagged spread, one-period lagged same and opposite side market depth, and limit order size) on the liquidity provision by trader types in a joint regression framework. ${ }^{4}$

Third, we compare our empirical results in a natural market setting with the empirical results of Bloomfield et al. (2005) on the changing liquidity provision by trader type in an experimental market setting.

We have obtained several interesting new results by trader types. (1) Our empirical results obtained from a natural market setting lend support to the empirical results of Bloomfield et al. (2005) on the intraday trading strategies of informed traders and uninformed traders in an experimental market setting. (2) Net limit order submissions by both institutional and individual traders have positive relations with one-period lagged transitory volatility and negative relationship with informational volatility. We have done a direct test on the prediction of Handa and Schwartz (1996) versus Foucault (1999) on the influence of transitory volatility and informational volatility on institutional versus individual trader's decision on selection of limit versus market orders. To the best of our knowledge, this is a new finding in limit order literature. (3) The net limit order submissions by foreign institutional traders and futures proprietary firm traders have a positive relationship with one period lagged spread; there is no significant relationship between lagged one period spreads and the limit order submissions by individual day traders and individual non-day traders. Finally, both the state of limit order book and order

\footnotetext{
${ }^{4}$ Previous papers only include a subset of our market condition variables we considered in their regression model. For example, Bae et al. (2003) did not include the state of limit order book variable in their regression. Bloomfield et al. (2005) examine the impact of each market condition variables separately on the submission of limit versus market orders by trader types in their experimental setting.
} 
size have significant influence on all types of trader's strategy on submission of limit order versus market order during the intraday trading session.

Our paper is organized as follows. Section 2 presents a literature review related to the impact of market conditions on the supply of liquidity by institutional versus individual traders in a limit order market. Section 3 describes the Taiwan index futures market structure and the data. Section 4 presents the empirical methodology. Empirical results are reported in Section 5, followed by summary and concluding remarks in Section 6 .

\section{Trader types, market conditions and liquidity provision in a limited order market}

In this section, we review alternative hypotheses and empirical evidence on (1) trading strategies of informed and uninformed traders and (2) the influence of market characteristics on traders' decisions on submission of limit versus market orders.

\subsection{Trading strategies of informed versus uninformed traders}

In a pure limit order market, traders face a decision on choice of limit orders or market orders. Market orders consume liquidity and are executed with certainty at the posted prices in the market. Limit orders supply liquidity and have the advantage of execution at a more favorable price than a market order. However, limit orders face execution uncertainty and an adverse selection risk because limit order price is fixed. Limit order traders provide free options to the arrival of informed traders (see Copland and Galai, 1983).

Earlier theoretical models (i.e., Glosten, 1994; Seppi, 1997; and others) assume that informed traders place market orders because they are impatient and private information is short 
lived while uninformed traders supply liquidity by submitting limit orders and wait for execution. Later theoretical models relax this restrictive assumption. For example, Chakravarty and Holden (1995) analyze the behavior of the informed trader in a single-period call-type market. They show that in this type of market the informed trader may simultaneously submit a market buy order and a limit sell order, and limit order acts as a safety net for the market order. This way, an optimal mix of limit order and market orders leads to a higher pay off than submitting only a market order when there is uncertainty about the price that a market order will fetch.

Harris (1998) develops optimal order submission strategies for trading problems faced by an informed trader, a uniformed trader and a value-motivated trader. He suggests that informed traders are more likely to use market orders when private information will soon become public, reflecting the desire of informed traders to realize their valuable private information. He also predicts that liquidity traders will start using limit orders and switching to market orders as the end of trading approaches in order to meet their target of trading. When informed traders face early deadline, they are going to employ market orders as well. Both informed and uninformed traders will submit limited orders when the deadline is distant and the bid-ask spread is large in order to minimize transaction costs. In general, he suggests that informed traders use relatively more market than limit orders.

Kaniel and Liu (2006) analyze informed traders' equilibrium choice of limit and market orders. They show that the time horizon of private information is positively related to the probability of using limit order by informed traders. Their empirical results show that informed traders prefer to use limit orders, which are indeed more informative.

Bloomfield et al. (2005) employ experimental asset markets to investigate the evolution of liquidity provisions by informed and liquidity traders in a pure limit order market. Their study focuses on how trading strategies are affected by trader type, market conditions and 
characteristics of the asset at different time points during a trading day. They find that informed traders use more market orders than limit orders at the earlier stage of trading session because informed traders are likely to capitalize on their private information. As the trading progresses, informed traders switch to liquidity provision. The change in the behavior of informed traders seems to be in response to dynamic adjustment of price to information. Informed traders perform better in terms of profit as liquidity suppliers because they have face less adverse selection risk when placing limit orders in comparison to uninformed traders.

This result suggests that informed traders take (provide) liquidity when the value of information is high (low). Uninformed traders supply relatively more liquidity in the earlier stage of the trading session and use relatively more market orders as trading nears the end because of their need to meet the target value of their trading purposes. Bloomfield et al. (2005) also document the difference in the impacts of market conditions (such as the volatility, the spread the state of limit order) on order choice between informed and uninformed traders. Their experimental results present a challenge to relax the assumptions of theoretical models and suggest an urgent need for a dynamic model on the order choice by trader types in a limit order market.

Anand, Charkravarty and Martell (2005) empirically investigate the evolution of liquidity and changing of trading strategies of institutional traders (i.e., informed traders), and they find that institutional traders use market orders more often in the first half than in the second half of the trading day. They also document that limit orders placed by institutional traders performed better than those placed by individual traders (i.e., uninformed traders). However, their tests were based the intraday data for the period from November 1990 to January 1991 obtained from NYSE, which is not a pure limit order market. 


\subsection{The influence of market characteristics on traders' decision on choice between limit and market orders}

The important market characteristic variables that affect the trader's choice on limit or market orders are volatility, spread, the state of limit order book and order size.

Handa and Schwartz (1996) develop a model to explain the rationale of trader choice of market or limit order and the profitability of limit order trading. In their model, the trader's choice depends on the probability of whether their limit order is executed against an informed trader or an uninformed (liquidity) trader. The execution of limit order suffers a loss with execution against an informed trader and gains profit when limit order execution against a liquidity trader. Thus, traders will submit more limit orders than market orders when the increase in price volatility is due to liquidity reasons because the profitability of limit order increases as traders increase in supply of liquidity. Thus, Handa and Schwartz (1996) predict a positive relationship between submission of limit order and transitory price volatility.

Foucault (1999) develops a model that explicitly incorporates a trader's decision to submit market versus limit order. He theorizes that when the asset volatility increases due to informed traders, the risk of adverse selection will increase. Thus, limit order traders have to increase their bid ask spreads to insure against losses. The cost of trading on market orders is less attractive and traders find it more cost-effective to trade using limit orders.

Ahn et al. (2001) use thirty-stock data from the SEHK from July 1996 to June 1997 and show that rise in transitory volatility is followed by increase in market depth due to increase in submission of limit orders. An increase in market depth is subsequently followed by a decrease in volatility. These results are consistent with the predication of the theoretical model of Handa and Schwartz (1996). Moreover, Bae et al. (2003) use a sample of 144 NYSE-list stocks over the 
period from November 1, 1990, to January 31 1991, to investigate trader's choice between limit and market orders. They find that traders use more limit orders when they expect an increase in transitory volatility. They find the impact of the asset (informational) volatility on trader's choice between limit and market orders is inclusive. Bloomfield et al. (2005) also find that volatility is one the major factors affecting both informed and uninformed trader's choice between limit and market orders.

Menkhoff et al. (2010) investigate the use of aggressive-price limit orders by informed traders versus uninformed traders in an ordered logit regression framework with data from the Moscow Interbank Currency Exchange. They show that volatility variable is negative and highly significant for informed traders and significant at $10 \%$ level for uninformed traders. Their results suggest that both types of traders will increase their use of limit orders following increase in volatility, but informed traders are more responsive to change in volatility than uninformed traders.

In addition, Menkhoff et al. (2010) also find that informed traders are more sensitive to change in the spreads, volatility and depths than uninformed traders in a pure limit market. There are two major concerns in their quality of data used in empirical tests: (1) the data lack trader identification code on trader type, causing the authors to assign a trader as either informed or uninformed based on the inference from the trade size and location information; and (2) the data cover only a seven intraday data period, which may be too short for reliable empirical tests.

Bias et al. (1995) provide empirical evidence that when spread is large, the conditional probability increases that investors place more limit orders than market orders. In contrast, traders use more market orders (i.e., hitting the quote) than limit orders when the spread is tight. Chung et al. (1999) examine limit order book and the bid-ask of 144 stocks traded in NYSE. They provide evidence that more traders submit limit orders when the spread is wide and use 
market orders when spread is tight. These results imply that when the spread is wide, traders place more limit orders, either because the submission of market orders is costly or because limit traders can be compensated by better price if limit orders are executed.

Previous literature has shown that the state of the limit order book influences a trader's order choice. Parlour (1998) provides a theoretical model that suggests traders are less likely to use limit orders if the limit book on the same side of the trade is thicker. This so-called "crowding out" effect arises because of the time priority of orders already in the book lowering the probability of execution of a new order at the same side. On the other hand, traders are more likely to use limit orders if the book on the other side of the trade is thicker. Bloomfield et al. (2005) examine this hypothesis in an experimental market setting. Their results lend support to the prediction of Parlour's model that traders would use more limit orders as the depth of the other side increases. They find that informed and liquidity traders behave differently in their limit order submission ratio for the same side of market depth. For example, the informed traders show higher limit order submission rates when the same side of the book is thicker as in the orders.

Based on order and transaction intraday data from the Swiss stock exchange, Ranaldo (2004) also demonstrates that patient traders become more order aggressive when their own (opposite) side book is thicker (thinner). Using limit order book information from the Australian Stock Exchange (ASX), Cao, Hansch and Wang (2008) provide additional empirical evidence that traders use more market orders when the same side of limit order book is thicker.

In general, traders have strong motives to minimize their trading cost when the order size is relatively larger. Bae et al. (2003) divided their sample into two order size groups: large and small. They provide evidence that, on average, traders in large order size group use more limit orders, ranging from $66 \%$ to $79 \%$ of the total orders in a trading day. In small order size group, 
$28 \%$ to $36 \%$ of the orders are limit orders. These results provide evidence that traders tend to use limit order when the order size is relatively large.

Given the results from previous literature, we use unique real world data to examine the differences among institutional, individual day and non-day traders in providing liquidity in response to change in market conditions during a trading day in a joint regression model.

\section{Taiwan index futures market structure and the data}

The Taiwan Futures Exchange (TAIFEX) is a pure order-driven market. Investors submit limit and market orders through brokers to the automated trading systems. Limit orders are consolidated into the electronic limit-order book. The Automated trading system (ATS) will order match and execute orders continuously with price-time priority rule, setting a single transaction price. Market buy (sell) orders will hit the best ask (bid) prices. The buy (sell) order with higher (lower) limit price than the set transaction price will be executed at the transaction price. Market participants can also submit cancel orders at any time prior to matching. The preopen session is from 8:30 to 8:45AM. During this period investors can submit limit and market orders to ATS system through brokers, and the exchange uses the single period auction system to establish the opening prices of regular trading hours. The regular trading hours conducted on weekdays excluding public holidays are from 8:45AM to 1:45PM. Limit orders are automatically cancelled at the end of trading day; thus we work with one day limit order book. There are no hidden orders.

TAIFEX disseminates order-and transaction prices to the public in real time. Investors can observe the anonymous best five bids and best five asks specific prices with the number of 
contracts from the screen. Since there are no designed market makers, liquidity is generated endogenously by orders of market participants.

Intraday tick by tick data of Taiwan stock index futures (FITX) obtained from TAIFEX are used in our analysis. Our sample period covers from January 1 2007, to December 2008. The contract size is the index value of FITX multiplied by 200 New Taiwan Dollars (NT\$). The maximum of each order size of TIFX is 100 contracts. We use nearby futures contracts in our analysis, and trading volume in the delivery month is used as the indicator to switch from first deferred contract to near-by futures contract. In our data editing process, we eliminate price limit days, time periods without limit order information and days with missing trading data. ${ }^{5}$ The dataset contains the detailed history of order flows, order book, transaction data and the identity of the traders. For each order, the date and time of arrival of the order, its direction (buy or sell initiation), the quantity demanded or supplied, and the trader identification are recorded. The trader identification enables us to categorize four types of traders: individual traders, domestic institution traders, futures proprietary firms and foreign institutional traders.

Panel A of Table 1 shows that the daily average trading volume is about 93,684 contracts. Individual traders account for 61 percent of the total daily average volume. Futures proprietary firms are different from futures brokers in that they trade for their own accounts to make profits and also make commissions by trading for clients. Their trading activity accounts for 23.34 percent of daily average total volume. Foreign Institutional traders executed about 12.26 percent and domestic institutional traders account for only 3.69 percent of daily average trading volume. ${ }^{6}$

\footnotetext{
${ }^{5}$ There are eight days in June 2008 and three days in December 2008 where data are missing.

${ }^{6}$ In the rest of our analysis, we concentrate only on activities of individual traders, foreign institutional traders and futures proprietary firm traders because the trading activity of domestic traders only accounts $3.69 \%$ of average daily trade volume. In addition, domestic institutional firms do not trade very frequently. As a result, we often face ineduqate observations of domestic institutional firms in our 15 minute time interval.
} 
Our analysis assumes that foreign institutional investors and futures proprietary firms are members of institutional traders and individual traders are uninformed or liquidity traders. ${ }^{7}$ From Panel A of Table 1, we can find that day trading in total trading volume accounts for about 30.4 percent, whereas individual non-day trading accounts for 30.31 percent of total volume. ${ }^{8}$ Our results are similar to the results reported by Barber et al. (2009), who find that day trading by individual traders is over 20 percent in the Taiwan stock market.

$<$ Table 1 is inserted about here>

\section{Empirical methodology}

Our empirical analysis consists of two steps. First, we use one way analysis of variance model to estimate the intraday submission patterns of limit orders, market orders and limit order submission ratios. Second, we use regression models to estimate the influences of market condition variables (i.e., Transitory_Volatility ${ }_{t-1}$, Informational_Volatility ${ }_{t-1}$, Spread $_{t-1}$, Same_Side_Depth ${ }_{t-1}$, Opposite_Side_Depth $h_{t-1}$, and Limt_Size $\left.e_{t}\right)$ on net limit order submission by institutional and individual traders.

In analysis of intraday variation patterns of order choices by trader types, we follow two principles to select the length of the time interval. Since we are interested in short time variations of limit versus market order submissions, the time interval should not be too long. On the other hand, if time interval is too short, there may not be enough observations for obtaining reliable

\footnotetext{
${ }^{7}$ Goetter et al. (2009, p68) suggest institutional traders are informed traders who view the current expected value of cash flow on the instrument. This implies that informed traders perform research on the value of the instrument while uninformed agents estimate the value of the instrument based on market observables.

${ }^{8}$ Day trader is defined as those traders who satisfy the following rule: the amount of contract purchased is equal to the amounts of contracts sold in the same trading day.
} 
estimates of intraday patterns. Balancing between these two guidelines, we decide to select a 15minute interval as the time interval of our intraday empirical analysis.

The one-way analysis of variance regression model is specified as follows:

$$
Y_{t}=\beta_{0}+\sum_{j=1}^{19} \beta_{j} D_{j, t}+e_{t}
$$

The dependent variable $Y_{t}$ is equal to the sum of limit orders in 15-minute time interval, or the sum of market orders in 15-minute time interval or limit order submission ratio in a 15minute interval. The value of intercept $\beta_{0}$ is equal to daily average as the basis of comparison. For this reason, we impose the following restriction as $\sum_{j=1}^{20} \beta_{j}=0$. The $D_{j, t}$ is the dummy variable which is equal to one if it is in jth interval, $\mathrm{j}=1,2,---, 19, D_{j, t}=0$ if it is not in the $j^{\text {th }}$ interval and equal to -1 if it is in $20^{\text {th }}$ time interval. ${ }^{9}$ The error term is $e_{t}$. The coefficient of $\beta_{j}$ is equal to the difference between the mean of $j^{\text {th }}$ time interval and the value of $\beta_{0}$, daily average. The sample mean of $j^{\text {th }}$ time interval is equal to the sum of the values of $\beta_{j}+\beta_{0}$. This model allows us to examine the influences of the role of the time interval on order submissions by trader type.

The regression model used to examine the influence of characteristics of market conditions

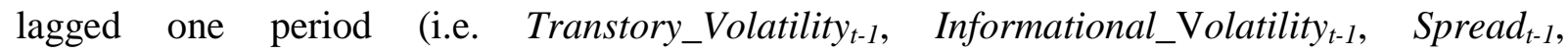
Same_Side_Depth ${ }_{t-1}$, and Other_Side_Depth $\left.{ }_{t-1}\right)$ and order size on liquidity provision by institutional and individual traders is specified as follows:

$$
\begin{aligned}
& \text { NLM } M_{t}=\alpha+\beta_{1} \text { Spread }_{t-1}+\beta_{2} \text { Transotory }_{-} \text {Volatility }_{t-1}+ \\
& \beta_{3} \text { Informational_Volatility } \\
& t-1 \\
& \beta_{5} \text { Other_Side_Depth } \beta_{t-1}+\beta_{6} \text { Same_Simit }_{-} \text {Size }_{t}+\sum_{j=1, j \neq 10}^{20} \beta_{7, j} D_{j}+\varepsilon_{t}
\end{aligned}
$$

\footnotetext{
${ }^{9}$ The estimated $\beta_{20}=-\left(\sum_{j=1}^{19} \beta_{j}\right)$.
} 
The dependent variable, the net sum of limit order $\left(N L M_{t}\right)$ denotes the sum of limit orders minus market orders and marketable limit orders during the 15 -minute interval. ${ }^{10}$ Spread $_{t-1}$ is the average of all dollar quote spreads during $t-1$ time period. The variable of Same_Side_Depth $h_{t-1}$ $\left(\right.$ Other_Side_Depth $\left.{ }_{t-1}\right)$ is measured as the average number of limit orders at the best bid (ask) just prior to a buy order's submission, and as the number at the best ask (bid) just prior to a sell order's submission at a given time in the $t-1$ time interval.

Previous literature documented that there is a positive relationship between total price volatility and submissions of limit order by traders. Handa and Schwartz (1996) proposed a hypothesis that an increase in transitory volatility will attract new limit order, and an increase in informational volatility will discourage submission of new limit orders because of increase in adverse selection risk. On other hand, Foucault (1999) shows that an increase in informational volatility will attract traders to submit more limit orders even traders face increasing adverse selection risk. During the increase in informational volatility periods, traders would face increase in trading costs due to higher bid-ask quotes posted by traders. Thus, market order trading is even more expensive than limit orders, and more traders find it optimal to implement their trades using limit orders.

In order to test these two competing hypotheses, total volatility is decomposed into two components: transitory volatility and informational volatility. To estimate transitory variance and informational variance, we assume transaction price follows a random walk model with transitory noise. It is a local level model and is specified as follows: ${ }^{11}$

\footnotetext{
${ }^{10}$ Marketable limit orders are limit orders that come with better quotes than the current best quotes in the order book.

${ }^{11}$ Further discussion on this unobserved component (local level) model is referred to by Harvey (1989). Hasbrouck (1996) has discussed this type of model with application to finance and Bae et al. (2003) applied this model to estimate to decompose the transaction into efficient and transitory price component.
} 


$$
\begin{array}{cc}
P_{t}=m_{t}+\xi_{t} & \xi_{t} \sim N I D\left(0, \sigma_{\xi}^{2}\right) \\
m_{t}=m_{t-1}+v_{t} & v_{t} \sim N I D\left(0, \sigma_{v}^{2}\right)
\end{array}
$$

where $P_{t}$ is transaction price and $m_{t}$ is unobserved equilibrium (efficient) price and it follows a random walk model. $\xi_{t}$ is transitory component. Kalman filter technique is used to estimate the parameters of the model (3) for each fifteen minute interval.

We use $\sigma_{\xi}$ as our measure of transitory volatility in 15-minutefifteen minute interval and $\sigma_{v}$ as our measure of informational volatility in fifteen minute interval. Bae et al. (2003) have used the model (3) to estimate intraday efficient price and transitory price for each day and then employ high-low price range in 30-minute interval to estimate the transitory and informational volatility respectively for each time interval. In our case, we obtain the estimates of transitory volatility and informational volatility from the empirical results of model (3) applied to each 15minute interval. Transtory_Volatility tr $_{\text {- }}$ (transitory volatility lagged one period) and Informational_Volatility t $_{\text {I }}$ (informational volatility lagged one period) are used to approximate trader's view on expected transitory and informational volatility in next time period.

We measure Limit_Size $_{t}$ as the average size of all limit order for all traders during the $t^{\text {th }}$ time interval. The dummy variables $D_{i, t}$ are the same as in the equation (1) and is used to control intraday variation of limit order submission patterns with respect to time.

We estimate both equations (1) and (2) for each type of traders using OLS. The Newey and West (1987) heteroskedasticity and autococorrelation consistent procedure is used to calculate the standard errors of estimates.

\section{Empirical Results}

This section consists of three parts: (1) empirical analysis of intraday variation patterns of limit and market orders by trader type, (2) empirical analysis of the influences of market 
conditions on liquidity provision by trader type over a course of a trading day and (3) robustness tests.

\subsection{Intraday variation of limit and mark orders by trader types}

The panels A, B and C of Table 2 presents average daily market and limit order submission by trader type for whole sample period, pre financial crisis period (2007/1 to 2007/07) and financial crisis period (2007/08- 2008/12) respectively. ${ }^{12}$ We sort all orders into pure market order, marketable limit order, and limit order. The numbers in parentheses for each row represent the percentages of order types for individual day traders, individual non-day traders, foreign institutional traders, and futures proprietary firm traders. The numbers in brackets represent the percentages of order types used by each trader type. For example, for the whole sample period, the total daily average order submissions of day traders is composed of $17.26 \%$ of pure market orders, $8.94 \%$ of marketable limit order and $73.80 \%$ of limit orders.

From Panel A ( whole sample) of Table 2, we observe several interesting: (1) on average, the sum of pure market order and marketable limit order submission accounts only for $16.76 \%$ whereas limit order submissions account for $83.24 \%$ of all orders; (2) individual day traders and non- day traders submit around $73.8 \%$ and $73.09 \%$ of their total orders in limit orders while foreign institutional traders and futures proprietary firms submit $94.1 \%$ and $92.62 \%$ limit orders in their total order submission, respectively. These results confirm that, in general, institutional traders use more limit orders than market orders. Our results are consistent with previous results by Kaniel and Liu (2006) and Bloomfield et al. (2005). But they do not support the prediction by Harris (1998) that informed traders use more market orders than limit orders. We find the order

\footnotetext{
${ }^{12}$ Following Brunnermeier (2009) as well as Melvin and Taylor (2009), the subprime crisis period starts from August 2007. We thus divide our sample period into pre financial crisis period (2007/1 to 2007/07) and financial crisis period (2007/08- 2008/12).
} 
types submission by traders in Panel C (financial crisis period) are very similar to the order submission types by trader types during whole sample period. This is not surprise because the time period of financial crisis period accounts for three fourth of the whole sample period. From Panel B ( pre-financial crisis period ( 2001/1 -2007/7) of Table 2, we find individual day traders uses slightly less percentage of market order and marketable limit orders and relatively more limit orders than corresponding percentages during the financial crisis period. We also observe that during pre financial crisis period, the sum of foreign institutional traders and futures proprietary firm accounts for $33 \%$ of average daily trading volume. On other hand, the sum of the percentage of their daily trading volume accounts for 52 percentages of daily trading volume. These results suggest that individual traders are trading more active in pre-financial crisis period and institutional traders are trading more active during the financial crisis period.

$<$ Table 2 is inserted about here $>$

Table 3 presents the regression analysis of intraday variation of limit and market orders by trader types on 15 -minute time intervals. ${ }^{13}$ The intercept is daily average and is used as the basis of comparison. We obtain several interesting findings from Table 3. They are as follows:

(1) In the pre-opening session (i.e., 8:30 to 8:45 AM), individual day traders and non-day traders are active in submitting limit orders while foreign institutional trader and futures proprietary firms are relatively inactive in submitting limit orders.

(2) Figure 1 show that the intraday average numbers of order submission for all trader types is $\mathrm{V}$ shaped for both market and limit orders. The second time interval (9:00 to 9:15AM) after the first opening time interval is the highest average number of order submissions for all type of

\footnotetext{
${ }^{13}$ Table A1 of the appendix is a supplement to Table 3. It presents the means of the numbers of limit and market orders submitted by trader type on a 15-minute time interval. Limit order submission ratio in Table A1 of the Appendix is the ratio of the mean of the number of limit orders to the sum of limit orders, market orders and marketable limit orders.
} 
traders. Our intraday pattern of order submissions is very similar to the patterns reported by Biais et al. (1995) and Bae et al. (2003).

Figure 2 (a) shows that the limit order submission ratio of institutional traders is inverted Ushaped during whole sample period. ${ }^{14}$ These results suggest that institutional traders use relatively more market orders at the beginning and closing time intervals. This is expected, in that institutional traders use more market orders to capture their value of private information in the early trading process and use relatively more market orders to close their positions as trading is close to the end. On the other hand, limit order submission ratios of individual day and nonday traders are similar to L-shaped with a sudden drop in the last two time intervals.

These results confirm that individual traders (i.e.uninformed traders) use relatively more limit orders in the early trading and use relatively more market orders as trading is close to the end of trading. These results suggest that individual traders provide relatively greater liquidity in the early session and consume relatively greater liquidity toward the end of trading session. Our results are consistent with the prediction made by Harris (1998) and empirical results reported by Bloomfield et al. (2005).

(4) The limit order submission ratio ranges from $83.97 \%$ to $93.12 \%$ for foreign institutional traders whereas it ranges from and $85.45 \%$ to $93 \%$ for futures proprietary firm traders, respectively. On the other hand, the limit order submission ratio of individual day and non-day traders is in the range from $67.53 \%$ to $79.7 \%$ and $66.67 \%$ to $76.34 \%$, respectively. These results support the results reported by Bloomfield et al. (2005) and Kaniel and Liu (2006) that informed traders use more limit orders than market orders and do not support the prediction of Harris (1998) that informed traders use relatively more market than limit orders.

\footnotetext{
${ }^{14}$ Limit order submission ratio is defined as the ratio of the number of limit order to the sum of limit and market orders during each 15-minute interval.
} 
(5) From Figure 2 (b), we observe that limit order submission ratios of all types traders during pre-financial crisis are very similar to limit order submission ratios of all trader types for whole sample period.

\section{$<$ Table 3 is inserted about here> \\ $<$ Figure 1 is inserted about here> \\ $<$ Figures 2 is inserted about here $>$}

Table 4 documents regression results on intraday variation of the size of limit order and market order submitted by all types of traders over a trading day. ${ }^{15}$ Figures 3 (a) and 3 (b) show the time series patterns of the limit order size and market order size by trader type, respectively. We find that (1) limit orders submitted by individual day traders, individual non-day traders and foreign institutional traders are larger in size than their corresponding market orders. These results affirm the results for all traders reported by Bae et al. (2003). However, futures proprietary firms hold exactly reverse pattern on submission of limit order size versus market order size.

(2) The intraday patterns of limit order size and market order size of both foreign institutional traders and futures proprietary firms are clearly L-shaped while flat for individual traders. The larger order sizes used by institutional traders than those used by individual traders suggest that institutional traders try to use larger order size to capture as much value of their market information as possible in the early stage of the trading process. These differences in intraday order size submission between institutional versus individual traders are new in limit

\footnotetext{
${ }^{15}$ Table A2 of the Appendix is a supplement to Table 4. It presents the means of the size of limit and market orders submitted by trader type on a 15-minute time interval. Market order size in Table A2 of the Appendix is mean of market order, which is sum of pure market order and marketable limit order.
} 
order market literature. Foreign institutional traders in general use larger sized limit order and market order size than those of the other three types of traders.

In summary, we find that institutional traders use relatively more market order in the early stage of trading process and switch to relatively more limit orders as the trading process progresses. On the other hand, individual traders submit relatively more limit orders in the early trading and use relatively more market orders as trading is close to the end.

<Table 4 is inserted about here>

$<$ Figure 3 is inserted about here>

\subsection{Regression analysis}

We report the regression analysis of the influences of market conditions on liquidity provision by trader types in Table 5. We do not present the results of dummy variables in order to save space.

For all traders (see column 2 in Table 5), the coefficient of Spread $_{t-1}$ is positive and highly significant at $1 \%$ level. This result confirms that when spread is wide, traders place more limit orders either because submission of market order is costly or because limit order can be compensated by better price if limited orders are executed (see Chung et al., 1999; Bea et al., 2003; and others). We find that the coefficient of transitory_volatility lagged one period has a positive sign and the coefficient of the informational_volatility has a negative sign; both of these coefficients are highly significant at the $1 \%$ level. Our empirical evidence is consistent with the prediction of theoretical model of Handa and Schwartz (1996) but does not support the implications of the model proposed by Foucault (1999).

In Handa and Schwartz's model, the traders suffer a loss with execution with informed traders due to adverse selection risk and gain profit when the limit orders against an uninformed 
(liquidity) traders. Thus, traders will submit more limit orders than market orders when there is an increase in the expected (one period lagged) transitory volatility and will decrease in submission of limit orders when expected informational volatility increases. Bae et al. (2003) also documented that traders will increase their submission of limit orders when transitory volatility is expected to increase, but the impact of informational volatility on submission of limit order is inconclusive. ${ }^{16}$

The parameter of same side depth at best bid ( ask) lagged one period has a negative sign and is significant at $1 \%$ level, and the parameter of opposite side depth lagged one period has a positive sign and is also significant at one percent level. As we expect, this result confirms that all traders will submit fewer limit orders when the state of the same side order book is thicker and more limit orders when the book is thinner. The impact of the state of the opposite side order book on limit order submissions by all traders has exactly the reverse effect of the state of the same side order book. This result confirms the theoretical prediction of Parlour (1998) and is also consistent with the experimental results obtained by Bloomfield et al. (2005). The positive and significant coefficient of the limit order size confirms that traders prefer to use more limit orders with the motives to minimize their trading cost when orders size are relatively large.

In columns 3-6 of Table 5, we report the regression results of the influence of market conditions on the liquidity provision by each type of traders. We summarize their differing responses of liquidity provision to changes in market conditions as follows:

(1) The coefficients of the spread lagged one period of individual day traders and individual non-day traders are positive, but not significant at $20 \%$ level. The coefficients of Spread $_{t-1}$ of

\footnotetext{
${ }^{16}$ We use transitory_ volatility and informational_ volatility as explanatory variables in the regression model, while Bae et al. (2003) use dummy variables to denote four combination cases of high and low transitory versus informational volatility cases.
} 
institutional traders (i.e., foreign institutional traders and futures proprietary firms) have positive signs and significant at least $1 \%$ level. The insignificant impact of change in spreads on the decision of individual day traders may be due to individual traders typically engaging in quick turn-around trading.

(2) The coefficient of the limit order size of for futures proprietary firms is negative and significant at $1 \%$ level. One possible explanation is that because futures proprietary firms often have access to order flow information, they often use market orders to capture the value of shortlived information. ${ }^{17}$

(3) The coefficients of Transitory_Volatility ${ }_{t-1}$, Informational_Volatility I $_{t}$, Same_Side_Depth $_{t-1}$ and Opposite_Side_Depth ${ }_{t-1}$ of all four types of traders have the same expected signs and are significant at $1 \%$ level. However, there are differences in their different response to net submission of limit orders due to changes in these market variables. Based on empirical results of Table 5, we estimate the elasticity of the limit order submission with respect to market condition variables and limit order size variable, and these results are reported in Table 6.

In general, institutional traders are more elastic to changes in these four lagged one period variables (i.e. Transtory_Volatility ${ }_{t-1}$, Informational_Volatility ${ }_{t-1}$ Spread $_{t-1}$, Same_Side_Depth It-1 $_{\text {, }}$ and Other_Side_Depth ${ }_{t-1}$ ) than individual day traders and individual non-day traders. For example, the elasticity of spreads lagged one period of foreign institutional traders and futures proprietary firm is 0.99 and 0.69 , respectively. The elasticity of spreads lagged one period is less than 0.01 and 0.08 for individual day traders and individual non-day traders, respectively. The

\footnotetext{
${ }^{17}$ We have interviewed several traders of futures proprietary futures firms. They informed us that they often hire large number of traders to monitor order flow from the order book and use relative large market order size to capture the instant trading opportunity. Traders of futures proprietary firms often use relative larger size of market orders than size of limit order size to implement their momentum trading strategy.
} 
elasticity of Informational_Volatility of foreign institutional traders and futures proprietary firm is -0.17 while the same elasticity for individual day traders and individual non-day traders are -0.12 and -0.008 , respectively. As expected, the elasticity of these market variables and limit order size for all (aggregate) traders are in the range of corresponding elasticity of these four types of traders. Our results support the finding by Menkhoff et al. (2010), which demonstrates that the order aggressiveness of informed traders is more response to market conditions than uninformed traders in ordered logit models.

$<$ Table 5 is inserted about here $>$

$<$ Table 6 is inserted about here>

\subsection{Robustness tests}

\subsubsection{Alternative measures of spreads and volatility}

To test the robustness of our empirical results for different measures of spread and volatility, we also use the percentage spread and two alternative measures of volatility: (a) we apply local level model (3) to decompose transaction price into efficient price and transitory price component for each 15-minute interval, and then we use the absolute values of the difference of $\log$ high and log low efficient and transitory price to estimate transitory volatility and informational volatility respectively in each 15 minute time interval; (b) another measure we

used is the realized variance. The realized variance is measured as $\sum_{i=1}^{N} r_{i, t}^{2}$ where $r_{i, t}$ is the return of $i^{\text {th }}$ transaction during time interval $t$, and $N$ denotes the total number of transaction during the time interval.

The merit of this volatility measure is that it includes both the transitory and asset (informational) volatility components. Furthermore, this measure reflects the cumulative price 
fluctuation rather than the average price fluctuation during the time interval. ${ }^{18} \mathrm{We}$ find the empirical results of the coefficients of the alternative measures of transitory and informational volatility with the rest of other explanatory variables are qualitatively similar to our current results. The empirical results of the second measure of volatility are positive and significant at less than 5\% level, and the signs and significance of other explanatory variables in this regression model are qualitatively similar to our current results.

\subsubsection{Alternative measures of time intervals and state of order book}

We also perform our analysis based on the half hour time interval and employ two new measures of states of order book: (1) Same_Side_Depth1-5 t-1 $_{-}$denotes the average of limit orders at the same bid (ask) sides from the (best) one to five price quotes during fifteen minutes interval lagged one period and (2) Other_Side_Depth1-5 $5_{t-1}$ is the average of limit orders at the opposite bid (ask) sides from the (best) one to five price quotes during fifteen minutes interval lagged one period. Table7 reports the regression results of the influence of market conditions on liquidity provision by trader type based on half hour time intervals and on two new measures of states of order book. Clearly, these empirical results are quite similar qualitatively to our regression results based on fifteen minute time intervals and the states of market depth measured at the best bid (ask) price quotes lagged one period.

$<$ Table 7 is inserted about here $>$

\section{Summary and concluding remarks}

\footnotetext{
${ }^{18}$ This measurement was used by Ahn et al. (2001) in their test of the hypothesis proposed by Handa and Schwartz (1996) on the influence of transitory volatility on selection of limit orders versus market orders by traders. It is well recognized that this measure contains both informational volatility and transitory volatility. Thus, it is an imperfect measure of transitory volatility.
} 
This study uses a unique dataset to examine the intraday liquidity provision by institutional traders (i.e., foreign institutional firms and futures proprietary firm traders) and individual traders (i.e., individual day traders and individual non-day traders) in the Taiwan index futures market. The data set consists of trader identification codes, trading activity, and the real time information in order books. Thus, our study is not subject to the trader-type classification error. We document the intraday changing trading strategies by trader type and also examine the influence of market conditions (i.e., one-period lagged transitory and informational volatility, one-period lagged spread, one-period lagged same and opposite side market depth, and limit order size) on the liquidity provision for each trader type in the regression models. The conclusions and contributions we consider to be important are as follows:

(1) In the Taiwan index futures market, foreign institutional traders and futures proprietary firm traders supply about $55 \%$ of liquidity in terms of the percentage of total limit order submitted to the market. Individual day traders and individual non-day traders demand $49.15 \%$ and $47.15 \%$ of liquidity, respectively, in terms of the percentage of the pure market orders. Thus, institutional traders play a relatively important role in providing liquidity. Foreign institutional traders and futures proprietary firm traders submit $94.1 \%$ and $92.6 \%$, respectively, of their total order submissions in limit orders. These results are consistent with previous results documented in Kaniel and Liu (2003) and Bloomfield et al. (2005) that informed traders use more limit orders than market orders.

(2) We find that the intraday average numbers of order submission for all trader types are Vshaped for both market and limit orders. We observe that the pattern of the limit order submission ratio of institutional traders is inverted U-shaped. These results suggest that institutional traders use relatively more market orders at the beginning and closing times of the trading day. On the other hand, the patterns of the limit order submission ratios of 
individual day and non-day traders are akin to an L-shape with a sudden drop at the last two time intervals. These results suggest that individual traders provide relatively greater liquidity in the early session and consume relatively greater liquidity close to the end of a trading session. Our results are consistent with the model prediction in Harris (1998) and empirical results reported in Bloomfield et al. (2005) on the changing trading strategies in an experimental market setting.

(3) In terms of order size, we find that the size of limit orders submitted by individual day traders, individual non-day traders and foreign institutional traders are larger than those of their corresponding market orders. The intraday patterns of the size of limit orders and of market orders for both foreign institutional traders and futures proprietary firm traders are clearly L-shaped, while the intraday patterns of limit order size and market order size for individual traders are flat-shaped. In general, foreign institutional traders use larger sized limit order and market order than those for other three types of traders. We believe this is a new empirical result never before documented in the limit order market literature.

(4) Results from the joint regression model indicate that the one-period lagged variables of transitory volatility, informational volatility, spreads and same side and opposite side market depths, and order size have correct signs and are highly significant statistically for all trader types. The coefficients of these market variables for foreign institutional investors are similar to those coefficients from all trader types' regression. We have obtained new interesting results that net limit order submissions by both institutional and individual traders have positive relations with one-period lagged transitory volatility and negative relationship with informational volatility. These results are consistent with the prediction of Handa and Schwartz (1996) on the influence of transitory volatility and 
informational volatility on trader's decision on selection of limit versus market orders by type of trades.

However, there are differences in coefficients of spreads and limit order size variables in net limit order submission regression for each trader type. For example, the one-period lagged spreads variable does not affect the decision of individual day traders. This result is expected because individual traders engage in quick turn-around trading. The coefficient of the limit order size for futures proprietary firm traders is negative and highly significant. One possible explanation is that futures proprietary firm traders, who often have access to order flow information, tend to use market orders often to capture the value of the short-lived information.

We also find that institutional traders are more elastic with respect to changes in one period lagged spread, transitory_volatility, informational_volatility, same side (opposite side) market depths and limit order size than individual day and non-day traders. Our results are consistent with those from the ordered logit models in Menkhoff et al. (2010). They show that the order aggressiveness of informed traders is more responsive to market conditions than that of uninformed traders.

In sum, our findings document the differences in impact of market variables on intraday order submission strategy by trader types. Our empirical results also serve as useful input for the developers of theoretical models that will predict the differences in liquidity provision by institutional versus individual traders in a real world market setting. 


\section{REFERENCES}

Ahn, H.J., Bae, K.H., Chan, K., 2001. Limit orders, depth, and volatility: Evidence from the stock exchange of Hong Kong. Journal of Finance 56, 767-788.

Anand, A., Chakravarty, S., Martell, T., 2005. Empirical evidence on the evolution of liquidity: Choice of market versus limit orders by informed and uninformed traders. Journal of Financial Markets 8, 289-309.

Bae, K.H., Jang, H., Park, K.S., 2003. Traders' choice between limit and market orders: Evidence from NYSE stocks. Journal of Financial Markets 6, 517-538.

Barber, B., Lee, Y.T., Liu, Y.J., Odean, T., 2009. Just how much do individual investor loss by trading? Review of Financial Studies 22, 609-632.

Biais, B., Hillion, P., Spatt, C., 1995. An empirical analysis of the limit order book and the order flow in the Paris Bourse. Journal of Finance 50, 1655-1689.

Bloomfield R., O'Hara M., Saar, G., 2005. The 'Make or Take' decision in an electronic market: Evidence on the evolution of liquidity. Journal of Financial Economics 75, 165-199.

Brunnermeier, M.K., 2009. Deciphering the liquidity and credit crunch 2007-2008. Journal of Economic Perspectives 23, 77-100.

Cao, C., Hansch O., Wang, X., 2008. Order placement strategies in a pure limit order book market. Journal of Financial Research, 31, 113-140.

Chakravarty, S., Holden, C., 1995. An integrated model of market and limit orders. Journal of Financial Intermediation 4, 213-241.

Chung, K.H., Van Ness, B.F., Van Ness, R.A., 1999. Limit orders and the bid-ask spread. Journal of Financial Economics 53, 255-287.

Copeland, T., Galai, D., 1983. Information effects on the bid-ask spread. Journal of Finance 38, 1457-1469.

Foucault, T., 1999. Order flow composition and trading cost in a dynamic limit order book. Journal of Financial Market 2, 99-134.

Glosten, L., 1994. Is the electronic open limit order book inevitable? Journal of Finance 49, 11271161.

Goettler, R.L., Parlour, C.A., Rajan, U., 2005. Equilibrium in a dynamic limit order market. Journal of Finance 60, 2149-2192.

Goettler, R.L., Parlour, C.A., Rajan, U., 2009. Informed traders and limit order markets. Journal of Financial Economics 93, 67-87.

Handa, P., Schwartz, R., 1996. Limit order trading. Journal of Finance 51, 1835-1861. 
Harvey, A.C., 1989. Forecasting, structural time series models and Kalman filter. Cambridge University Press.

Hasbrouck, J., 1996. Modeling market microstructure time series. In: Maddala, G, S., Rao, C.R., (Eds.). Handbook of Statistics, Vol. 14, 647-692.

Harris, L., 1998. Optimal dynamic order submission strategies in some stylized trading problems. Financial Markets, Institutions and Instruments 7.

Kaniel, R., Liu, H., 2006. So what orders do informed traders use? Journal of Business 79, 1867 1913.

Keim, D., Madhaven, A., 1995. Anatomy of the trading process: empirical evidence on the behavior of institutional traders. Journal of Financial Economics 37, 371-398.

Melvin, M., Taylor, M.P., 2009. The crisis in the foreign exchange market. Journal of International Money and Finance 28, 1317-1330.

Menkhoff, L., Osler, C.L., Schmeling, M., 2010. Limit-order submission strategies under asymmetric information. Journal of Banking and Finance 34, 2665-2677.

Newey, W., West K,1987. A simple positive semi-definete heteroskedastic and autocorrelation consistent covariance matrix, Econometrica 55,703-708.

Parlour, C.A., 1998. Price dynamics in limit order markets. Review of Financial Studies 11, 786816.

Parlour, C.A., Seppi, D.J., 2008. Limit order markets: a survey. In: Boot, A.W.A., Thakor, A.V., (Eds.). Handbook of Financial Intermediation and Banking 5.

Ranaldo, A., 2004. Order aggressiveness in limit order book markets. Journal of Financial Markets 7, 53-74.

Rosu, I., 2009. A dynamic model of the limit order book. Review of Financial Studies 22, 46014641.

Seppi, D.J., 1997. Liquidity provision with limit orders and a strategic specialist. Review of Financial Studies 10, 103-150. 
Table 1: Daily trading volume statistics by trader type

\begin{tabular}{|c|c|c|c|c|c|c|}
\hline & \multicolumn{2}{|c|}{$\begin{array}{l}\text { Individual Traders } \\
\qquad(\%)\end{array}$} & \multirow{2}{*}{$\begin{array}{c}\text { Domestic } \\
\text { Institutional } \\
\text { Traders (\%) }\end{array}$} & \multirow{2}{*}{$\begin{array}{c}\text { Foreign } \\
\text { Institutional } \\
\text { Traders (\%) }\end{array}$} & \multirow{2}{*}{$\begin{array}{c}\text { Futures } \\
\text { Proprietary } \\
\text { Firms (\%) }\end{array}$} & \multirow{2}{*}{$\begin{array}{c}\text { Total Daily } \\
\text { Average }\end{array}$} \\
\hline & $\begin{array}{c}\text { Day } \\
\text { Trader } \\
(\%)\end{array}$ & $\begin{array}{c}\text { Non- } \\
\text { Day } \\
\text { Trader } \\
(\%) \\
\end{array}$ & & & & \\
\hline \multicolumn{7}{|c|}{ Panel A: percentage of total volume by trader type } \\
\hline $\begin{array}{l}\text { Trading } \\
\text { volume }\end{array}$ & 30.40 & 30.31 & 3.69 & 12.26 & 23.34 & $93,683.69$ \\
\hline \multicolumn{7}{|c|}{ Panel B: percentage of total volume of day trading versus non-day trading by trader type } \\
\hline $\begin{array}{l}\text { Day } \\
\text { Trading }\end{array}$ & & $\begin{array}{l}78) \\
06]\end{array}$ & $\begin{array}{c}(1.54) \\
{[13.40]}\end{array}$ & $\begin{array}{l}(2.83) \\
{[7.41]}\end{array}$ & $\begin{array}{l}(0.85) \\
{[1.17]}\end{array}$ & $\begin{array}{c}30,044.36(100) \\
{[32.07]}\end{array}$ \\
\hline $\begin{array}{l}\text { Non-Day } \\
\text { Trading }\end{array}$ & & 64) & $\begin{array}{c}(4.70) \\
{[86.60]}\end{array}$ & $\begin{array}{l}(16.71) \\
{[92.59]}\end{array}$ & $\begin{array}{l}(33.96) \\
{[98.83]}\end{array}$ & $\begin{array}{c}63,639.33(100) \\
{[67.93]}\end{array}$ \\
\hline Total & $\begin{array}{r}56, \\
(6 \\
{[}\end{array}$ & $\begin{array}{l}5.37 \\
72) \\
0]\end{array}$ & $\begin{array}{c}3,456.93 \\
(3.69) \\
{[100]}\end{array}$ & $\begin{array}{c}11,485.62 \\
(12.26) \\
{[100]}\end{array}$ & $\begin{array}{c}21,865.77 \\
(23.34) \\
{[100]}\end{array}$ & $\begin{array}{c}93,683.69(100) \\
{[100]}\end{array}$ \\
\hline
\end{tabular}

Note: The table provides daily trading volume statistics by trader type in the Taiwan Stock Exchange index futures (FITX) from January 1, 2007 to December 31, 2008. In Panel A, we show the percentage of daily trading volume for Individual Day Traders, Individual Non-Day Traders, Domestic Institutional Traders, Foreign Institutional Traders, and Futures Proprietary firms Traders. In Panel B, we separate trading volume into day trading and nonday trading. The numbers in parentheses in each row represent the percentages of day trading and non-day trading by trader type. The numbers in brackets in each column represent the percentages of day trading and non-day trading for each trader type. For example, among foreign institutional traders, $7.41 \%$ engage in day trading and $92.5 \%$ engage in non-day trading. A trader is defined as a day trader when the amounts of contracts purchased and sold are the same in a specific day. 
Table 2: Daily order book statistics by trader type categories

\begin{tabular}{|c|c|c|c|c|c|}
\hline & \multicolumn{2}{|c|}{ Individual Trader } & \multirow{2}{*}{$\begin{array}{c}\text { Foreign } \\
\text { Institutional } \\
\text { Traders }(\%)\end{array}$} & \multirow{2}{*}{$\begin{array}{c}\text { Futures } \\
\text { Proprietary Firm } \\
\text { Traders }(\%)\end{array}$} & \multirow{2}{*}{$\begin{array}{c}\text { Total Daily } \\
\text { Average Orders }\end{array}$} \\
\hline & $\begin{array}{l}\text { Day Trader } \\
(\%)\end{array}$ & $\begin{array}{l}\text { Non Day } \\
\text { Trader }(\%)\end{array}$ & & & \\
\hline \multicolumn{6}{|c|}{ Panel A: Full Sample Period (2007/1 2008/12) } \\
\hline Pure Market & $(49.15)$ & $(47.15)$ & $(1.57)$ & $(2.13)$ & $22,465.46(100)$ \\
\hline Order & {$[17.26]$} & {$[17.48]$} & {$[0.57]$} & {$[0.82]$} & {$[9.17]$} \\
\hline Marketable & $(30.80)$ & $(30.74)$ & $(17.75)$ & $(20.71)$ & $18,581.06(100)$ \\
\hline Limit Order & [8.94] & [9.43] & {$[5.35]$} & {$[6.56]$} & [7.59] \\
\hline \multirow{2}{*}{ Limit Order } & $(23.16)$ & $(21.73)$ & $(28.48)$ & $(26.63)$ & $203,841.30(100)$ \\
\hline & [73.80] & [73.09] & [94.08] & [92.62] & [83.24] \\
\hline Total Daily & $63,981.86$ & $60,590.68$ & $61,705.38$ & $58,609.91$ & \multirow{3}{*}{$\begin{array}{c}244,887.84(100) \\
{[100]}\end{array}$} \\
\hline Order & $(26.13)$ & $(24.74)$ & $(25.20)$ & $(23.93)$ & \\
\hline Average & [100] & [100] & {$[100]$} & {$[100]$} & \\
\hline \multicolumn{6}{|c|}{ Panel B: Pre financial crisis-2007/01 2007/07 } \\
\hline Pure Market & $(38.87)$ & $(56.41)$ & $(1.50)$ & $(3.22)$ & $14,278.45(100)$ \\
\hline Order & [12.73] & [15.53] & {$[0.95]$} & {$[1.80]$} & [9.95] \\
\hline Marketable & $(22.93)$ & $(37.36)$ & $(17.16)$ & $(22.54)$ & $11,040.01(100)$ \\
\hline Limit Order & {$[5.81]$} & [7.95] & {$[8.43]$} & [9.73] & [7.69] \\
\hline \multirow{2}{*}{ Limit Order } & $(30.04)$ & $(33.58)$ & $(17.23)$ & $(19.14)$ & $118,185.89(100)$ \\
\hline & {$[81.46]$} & [76.52] & [90.62] & {$[88.47]$} & {$[82.36]$} \\
\hline Total Daily & $43,589.69$ & $51,871.18$ & $22,472.08$ & $25,571.40$ & \multirow{3}{*}{$\begin{array}{c}143,504.35(100) \\
{[100]}\end{array}$} \\
\hline Order & $(30.38)$ & $(36.15)$ & $(15.66)$ & $(17.82)$ & \\
\hline Average & [100] & [100] & {$[100]$} & {$[100]$} & \\
\hline \multicolumn{6}{|c|}{ Panel C: During financial crisis-2007/08 2008/12 } \\
\hline Pure Market & $(51.48)$ & $(45.06)$ & $(1.57)$ & $(1.89)$ & $25,818.09(100)$ \\
\hline Order & {$[18.37]$} & {$[18.13]$} & {$[0.52]$} & {$[0.67]$} & [9.01] \\
\hline Marketable & (32.44) & $(29.36)$ & $(17.88)$ & $(20.32)$ & $21,673.68(100)$ \\
\hline Limit Order & {$[9.72]$} & [9.92] & [4.98] & {$[6.10]$} & {$[7.57]$} \\
\hline \multirow{2}{*}{ Limit Order } & $(21.77)$ & $(19.32)$ & $(30.76)$ & $(28.15)$ & $238,950.09(100)$ \\
\hline & [71.91] & [71.95] & [94.49] & [93.22] & [83.42] \\
\hline Total Daily & $72,340.28$ & $64,164.67$ & $77,785.05$ & $72,151.86$ & \multirow{3}{*}{$\begin{array}{c}286,441.86(100) \\
{[100]}\end{array}$} \\
\hline Order & $(25.25)$ & $(22.40)$ & $(27.16)$ & $(25.19)$ & \\
\hline Average & [100] & [100] & [100] & [100] & \\
\hline
\end{tabular}

Note: The table presents a daily order book statistics by trader type in the futures contract FITX from whole sample period, pre-financial crisis and during financial crisis periods. We divided all order books into the pure market order, marketable limit order, and limit order. The numbers in parentheses for each row represent the percentages of order types by Individual Day Traders, Individual Non-Day Traders, Foreign Institutional Traders, and Futures Proprietary Firm Traders. The numbers in brackets for each column represent the percentages of order types by each trader types. For example, during whole sample period, the total daily average orders of day traders, there are [17.26]\% is pure market orders,[8.94]\% is marketable limit order and [73.80] 5 is limit orders. 
Table 3: Regression analysis of intraday variation patterns of limit and market orders by type of traders

\begin{tabular}{|c|c|c|c|c|c|c|c|c|c|c|c|c|}
\hline \multirow[b]{2}{*}{ Time Interval } & \multicolumn{3}{|c|}{ Individual Day Traders } & \multicolumn{3}{|c|}{ Individual Non Day Traders } & \multicolumn{3}{|c|}{ Foreign Institutional Traders } & \multicolumn{3}{|c|}{ Futures Proprietary Firm Traders } \\
\hline & Limit & Market & $\begin{array}{c}\text { Limit Order } \\
\text { Submission } \\
\text { Ratio }(\%)\end{array}$ & Limit & Market & $\begin{array}{c}\text { Limit Order } \\
\text { Submission } \\
\text { Ratio }(\%)\end{array}$ & Limit & Market & $\begin{array}{c}\text { Limit Order } \\
\text { Submission } \\
\text { Ratio }(\%)\end{array}$ & Limit & Market & $\begin{array}{c}\text { Limit Order } \\
\text { Submission } \\
\text { Ratio }(\%)\end{array}$ \\
\hline $08: 30-08: 45^{\#}$ & $\begin{array}{c}-1168.70^{* * *} \\
(-21.13)\end{array}$ & $\begin{array}{c}-684.71^{* * *} \\
(-25.36)\end{array}$ & $\begin{array}{c}0.1485^{* * *} \\
(46.70)\end{array}$ & $\begin{array}{c}-655.68^{* * *} \\
(-14.37)\end{array}$ & $\begin{array}{c}-414.46^{* * *} \\
(18.04)\end{array}$ & $\begin{array}{c}0.0700^{* * * *} \\
(23.09)\end{array}$ & $\begin{array}{c}-2628.85^{* * *} \\
(-18.84)\end{array}$ & $\begin{array}{c}-116.95^{* * *} \\
(-12.27)\end{array}$ & $\begin{array}{c}-0.2364^{* * *} \\
(-47.42)\end{array}$ & $\begin{array}{c}-2155.82^{* * * *} \\
(-20.06)\end{array}$ & $\begin{array}{c}-149.27^{* * *} \\
(17.44)\end{array}$ & $\begin{array}{c}-0.0348^{* * *} \\
(-13.93)\end{array}$ \\
\hline 1. $08: 45-09: 00$ & $\begin{array}{c}152.44^{* * * *} \\
(2.75)\end{array}$ & $\begin{array}{c}-152.80^{* * * *} \\
(-5.64)\end{array}$ & $\begin{array}{c}0.0415^{* * *} \\
(13.00)\end{array}$ & $\begin{array}{c}1102.33^{* * * *} \\
(24.06)\end{array}$ & $\begin{array}{c}539.62^{* * * *} \\
(23.39)\end{array}$ & $\begin{array}{c}-0.0256^{* * *} \\
(-8.41)\end{array}$ & $\begin{array}{c}-298.62^{* *} \\
(-2.13)\end{array}$ & $\begin{array}{c}79.55^{* * *} \\
(8.31)\end{array}$ & $\begin{array}{c}-0.0166^{* * * *} \\
(-3.31)\end{array}$ & $\begin{array}{c}403.85^{* * * *} \\
(3.74)\end{array}$ & $\begin{array}{c}100.71^{* * *} \\
(11.72)\end{array}$ & $\begin{array}{c}-0.0155^{* * * *} \\
(-6.19)\end{array}$ \\
\hline 2. 09:00-09:15 & $\begin{array}{c}805.39^{* * * *} \\
(14.52)\end{array}$ & $\begin{array}{c}295.95^{* * *} \\
(10.93)\end{array}$ & $\begin{array}{c}-0.0118^{* * * *} \\
(-3.71)\end{array}$ & $\begin{array}{c}649.68^{* * * *} \\
(14.20)\end{array}$ & $\begin{array}{c}406.30^{* * * *} \\
(17.63)\end{array}$ & $\begin{array}{c}-0.0407^{* * * *} \\
(-13.38)\end{array}$ & $\begin{array}{c}1031.12^{* * *} \\
(7.37)\end{array}$ & $\begin{array}{c}128.31^{* * * *} \\
(13.42)\end{array}$ & $\begin{array}{c}0.0021 \\
(0.43)\end{array}$ & $\begin{array}{c}964.08^{* * * *} \\
(8.95)\end{array}$ & $\begin{array}{c}133.07^{* * * *} \\
(15.50)\end{array}$ & $\begin{array}{c}-0.0154^{\text {**** }} \\
(-6.16)\end{array}$ \\
\hline 3. $09: 15-09: 30$ & $\begin{array}{c}664.03^{* * *} \\
(11.97)\end{array}$ & $\begin{array}{c}227.12^{* * * *} \\
(8.39)\end{array}$ & $\begin{array}{c}-0.0050 \\
(-1.58)\end{array}$ & $\begin{array}{c}451.81^{* * * *} \\
(9.87)\end{array}$ & $\begin{array}{c}215.21^{* * * *} \\
(9.34)\end{array}$ & $\begin{array}{c}-0.0194^{* * * *} \\
(-6.37)\end{array}$ & $\begin{array}{c}1035.06^{* * *} \\
(7.40)\end{array}$ & $\begin{array}{c}57.47^{* * *} \\
(6.01)\end{array}$ & $\begin{array}{c}0.0157^{* * *} \\
(3.14)\end{array}$ & $\begin{array}{c}687.73^{* * *} \\
(6.38)\end{array}$ & $\begin{array}{c}66.97^{* * * *} \\
(7.80)\end{array}$ & $\begin{array}{c}-0.0056^{* *} \\
(-2.23)\end{array}$ \\
\hline 4. 09:30-09:45 & $\begin{array}{c}401.64^{* * * *} \\
(7.25)\end{array}$ & $\begin{array}{c}125.80^{* * * *} \\
(4.65)\end{array}$ & $\begin{array}{c}-0.0022 \\
(-0.67)\end{array}$ & $\begin{array}{c}225.18^{* * *} \\
(4.92)\end{array}$ & $\begin{array}{c}49.37^{* *} \\
(2.14)\end{array}$ & $\begin{array}{c}-0.0019 \\
(-0.61)\end{array}$ & $\begin{array}{c}723.01^{* * * *} \\
(5.17)\end{array}$ & $\begin{array}{l}16.76^{*} \\
(1.75)\end{array}$ & $\begin{array}{c}0.0204^{* * *} \\
(4.09)\end{array}$ & $\begin{array}{c}406.30^{* * * *} \\
(3.77)\end{array}$ & $\begin{array}{c}20.00^{* *} \\
(2.33)\end{array}$ & $\begin{array}{c}-0.0030 \\
(-1.19)\end{array}$ \\
\hline 5. 09:45-10:00 & $\begin{array}{c}333.06^{* * *} \\
(6.01)\end{array}$ & $\begin{array}{c}119.52^{* * *} \\
(4.41)\end{array}$ & $\begin{array}{c}-0.0033 \\
(-1.05)\end{array}$ & $\begin{array}{c}164.06^{* * *} \\
(3.58)\end{array}$ & $\begin{array}{l}39.79^{*} \\
(1.73)\end{array}$ & $\begin{array}{c}-0.0035 \\
(-1.16)\end{array}$ & $\begin{array}{c}491.88^{* * *} \\
(3.52)\end{array}$ & $\begin{array}{c}-0.71 \\
(-0.07)\end{array}$ & $\begin{array}{c}0.0180^{* * *} \\
(3.60)\end{array}$ & $\begin{array}{c}246.97^{* *} \\
(2.29)\end{array}$ & $\begin{array}{l}15.78^{*} \\
(1.84)\end{array}$ & $\begin{array}{c}0.0006 \\
(0.24)\end{array}$ \\
\hline 6. $10: 00-10: 15$ & $\begin{array}{c}177.62^{* * *} \\
(3.20)\end{array}$ & $\begin{array}{c}84.70^{* * *} \\
(3.12)\end{array}$ & $\begin{array}{c}-0.0075^{* *} \\
(-2.36)\end{array}$ & $\begin{array}{l}27.14 \\
(0.59)\end{array}$ & $\begin{array}{l}-28.82 \\
(-1.25)\end{array}$ & $\begin{array}{c}0.0039 \\
(1.27)\end{array}$ & $\begin{array}{r}240.23^{*} \\
(1.72)\end{array}$ & $\begin{array}{l}-11.49 \\
(-1.20)\end{array}$ & $\begin{array}{c}0.0165^{* * *} \\
(3.29)\end{array}$ & $\begin{array}{l}42.28 \\
(0.39)\end{array}$ & $\begin{array}{c}-3.77 \\
(-0.44)\end{array}$ & $\begin{array}{c}0.0038 \\
(1.52)\end{array}$ \\
\hline 7. $10: 15-10: 30$ & $\begin{array}{l}65.48 \\
(1.18)\end{array}$ & $\begin{array}{l}48.80^{*} \\
(1.79)\end{array}$ & $\begin{array}{c}-0.0074^{* *} \\
(-2.32)\end{array}$ & $\begin{array}{c}-85.27^{*} \\
(-1.86)\end{array}$ & $\begin{array}{c}-88.19^{* * *} \\
(-3.81)\end{array}$ & $\begin{array}{c}0.0108^{* * *} \\
(3.52)\end{array}$ & $\begin{array}{l}-20.64 \\
(-0.15)\end{array}$ & $\begin{array}{c}-28.78^{* * *} \\
(-3.00)\end{array}$ & $\begin{array}{c}0.0179^{* * *} \\
(3.57)\end{array}$ & $\begin{array}{l}-40.80 \\
(-0.38)\end{array}$ & $\begin{array}{c}-19.85^{* *} \\
(-2.30)\end{array}$ & $\begin{array}{c}0.0065^{\text {*** }} \\
(2.58)\end{array}$ \\
\hline 8. $10: 30-10: 45$ & $\begin{array}{c}-146.42^{* * *} \\
(-2.63)\end{array}$ & $\begin{array}{l}-24.76 \\
(-0.91)\end{array}$ & $\begin{array}{c}-0.0070^{* *} \\
(-2.20)\end{array}$ & $\begin{array}{c}-272.59^{* * *} \\
(-5.94)\end{array}$ & $\begin{array}{c}-158.27^{* * *} \\
(-6.85)\end{array}$ & $\begin{array}{c}0.0127^{* * *} \\
(4.18)\end{array}$ & $\begin{array}{c}-149.69 \\
(-1.07)\end{array}$ & $\begin{array}{c}-39.72^{* * * *} \\
(-4.15)\end{array}$ & $\begin{array}{c}0.0231^{* * *} \\
(4.62)\end{array}$ & $\begin{array}{c}-148.53 \\
(-1.38)\end{array}$ & $\begin{array}{c}-50.27^{* * *} \\
(-5.85)\end{array}$ & $\begin{array}{c}0.0139^{\text {**** }} \\
(5.54)\end{array}$ \\
\hline 9. $10: 45-11: 00$ & $\begin{array}{c}-139.04^{* *} \\
(-2.50)\end{array}$ & $\begin{array}{c}1.99 \\
(0.07)\end{array}$ & $\begin{array}{c}-0.0104^{* * *} \\
(-3.25)\end{array}$ & $\begin{array}{c}-224.96^{* * * *} \\
(-4.91)\end{array}$ & $\begin{array}{c}-133.88^{* * *} \\
(-5.80)\end{array}$ & $\begin{array}{c}0.0134^{* * *} \\
(4.39)\end{array}$ & $\begin{array}{c}-157.45 \\
(-1.12)\end{array}$ & $\begin{array}{c}-46.67^{* * *} \\
(-4.87)\end{array}$ & $\begin{array}{c}0.0246^{* * *} \\
(4.90)\end{array}$ & $\begin{array}{l}-69.53 \\
(-0.64)\end{array}$ & $\begin{array}{c}-31.88^{* * *} \\
(-3.71)\end{array}$ & $\begin{array}{c}0.0115^{\text {*** }} \\
(4.59)\end{array}$ \\
\hline 10. $11: 00-11: 15$ & $\begin{array}{c}-231.09^{* * *} \\
(-4.15)\end{array}$ & $\begin{array}{c}-53.07^{* *} \\
(-1.96)\end{array}$ & $\begin{array}{c}-0.0072^{* *} \\
(-2.23)\end{array}$ & $\begin{array}{c}-335.43^{* * *} \\
(-7.30)\end{array}$ & $\begin{array}{c}-181.31^{* * *} \\
(-7.84)\end{array}$ & $\begin{array}{c}0.0168^{* * *} \\
(5.51)\end{array}$ & $\begin{array}{c}-313.47^{* *} \\
(-2.23)\end{array}$ & $\begin{array}{c}-43.35^{* * *} \\
(-4.52)\end{array}$ & $\begin{array}{c}0.0183^{* * *} \\
(3.64)\end{array}$ & $\begin{array}{c}-223.57^{* *} \\
(-2.07)\end{array}$ & $\begin{array}{c}-50.84^{* * *} \\
(-5.90)\end{array}$ & $\begin{array}{c}0.0132^{* * * *} \\
(5.25)\end{array}$ \\
\hline 11. $11: 15-11: 30$ & $\begin{array}{c}-125.02^{* *} \\
(-2.24)\end{array}$ & $\begin{array}{c}8.82 \\
(0.32)\end{array}$ & $\begin{array}{c}-0.0146^{* * *} \\
(-4.55)\end{array}$ & $\begin{array}{c}-218.28^{\text {*** }} \\
(-4.75)\end{array}$ & $\begin{array}{c}-112.19^{* * *} \\
(-4.84)\end{array}$ & $\begin{array}{c}0.0095^{* * *} \\
(3.10)\end{array}$ & $\begin{array}{c}-281.79^{* *} \\
(-2.00)\end{array}$ & $\begin{array}{c}-35.50^{* * * *} \\
(-3.70)\end{array}$ & $\begin{array}{c}0.0200^{* * *} \\
(3.99)\end{array}$ & $\begin{array}{l}-93.56 \\
(-0.86)\end{array}$ & $\begin{array}{c}-24.74^{* * *} \\
(-2.87)\end{array}$ & $\begin{array}{c}0.0092^{* * * *} \\
(3.64)\end{array}$ \\
\hline 12. $11: 30-11: 45$ & $\begin{array}{l}24.15 \\
(0.43)\end{array}$ & $\begin{array}{l}35.66 \\
(1.31)\end{array}$ & $\begin{array}{c}-0.0084^{* * *} \\
(-2.61)\end{array}$ & $\begin{array}{c}-176.89^{\text {*** }} \\
(-3.85)\end{array}$ & $\begin{array}{c}-99.71^{* * *} \\
(-4.31)\end{array}$ & $\begin{array}{c}0.0089^{* * *} \\
(2.91)\end{array}$ & $\begin{array}{c}-127.11 \\
(-0.91)\end{array}$ & $\begin{array}{c}-32.63^{* * *} \\
(-3.40)\end{array}$ & $\begin{array}{c}0.0203^{* * *} \\
(4.05)\end{array}$ & $\begin{array}{l}9.33 \\
(0.09)\end{array}$ & $\begin{array}{c}-20.99^{* *} \\
(-2.44)\end{array}$ & $\begin{array}{c}0.0081^{* * * *} \\
(3.24)\end{array}$ \\
\hline 13. $11: 45-12: 00$ & $\begin{array}{c}-4.42 \\
(-0.08)\end{array}$ & $\begin{array}{l}41.34 \\
(1.52)\end{array}$ & $\begin{array}{c}-0.0123^{* * *} \\
(-3.84)\end{array}$ & $\begin{array}{c}-186.26^{\text {**** }} \\
(-4.05)\end{array}$ & $\begin{array}{c}-81.67^{* * *} \\
(-3.52)\end{array}$ & $\begin{array}{c}0.0023 \\
(0.76)\end{array}$ & $\begin{array}{l}-15.58 \\
(-0.11)\end{array}$ & $\begin{array}{c}-37.59^{* * *} \\
(-3.91)\end{array}$ & $\begin{array}{c}0.0214^{* * *} \\
(4.25)\end{array}$ & $\begin{array}{l}-36.41 \\
(-0.34)\end{array}$ & $\begin{array}{c}-21.67^{* *} \\
(-2.51)\end{array}$ & $\begin{array}{c}0.0108^{* * *} \\
(4.30)\end{array}$ \\
\hline
\end{tabular}


Table 3 (Continue): Regression analysis of intraday variation patterns of limit and market orders by type of traders

\begin{tabular}{|c|c|c|c|c|c|c|c|c|c|c|c|c|}
\hline \multirow[b]{2}{*}{ Time Interval } & \multicolumn{3}{|c|}{ Individual Day Traders } & \multicolumn{3}{|c|}{ Individual Non Day Traders } & \multicolumn{3}{|c|}{ Foreign Institutional Traders } & \multicolumn{3}{|c|}{ Futures Proprietary Firm Traders } \\
\hline & Limit & Market & $\begin{array}{c}\text { Limit Order } \\
\text { Submission } \\
\text { Ratio }(\%)\end{array}$ & Limit & Market & $\begin{array}{l}\text { Limit Order } \\
\text { Submission } \\
\text { Ratio }(\%)\end{array}$ & Limit & Market & $\begin{array}{c}\text { Limit Order } \\
\text { Submission } \\
\text { Ratio }(\%)\end{array}$ & Limit & Market & $\begin{array}{c}\text { Limit Order } \\
\text { Submission } \\
\text { Ratio }(\%)\end{array}$ \\
\hline 14. $12: 00-12: 15$ & $\begin{array}{l}-66.85 \\
(-1.20)\end{array}$ & $\begin{array}{l}13.64 \\
(0.50)\end{array}$ & $\begin{array}{c}-0.0074^{* *} \\
(-2.29)\end{array}$ & $\begin{array}{c}-304.69^{* * *} \\
(-6.61)\end{array}$ & $\begin{array}{c}-114.73^{* * *} \\
(-4.94)\end{array}$ & $\begin{array}{c}0.0050^{*} \\
(1.65)\end{array}$ & $\begin{array}{l}82.20 \\
(0.58)\end{array}$ & $\begin{array}{c}-38.12^{* * * *} \\
(-3.96)\end{array}$ & $\begin{array}{c}0.0234^{* * *} \\
(4.66)\end{array}$ & $\begin{array}{l}-97.33 \\
(-0.90)\end{array}$ & $\begin{array}{c}-28.90^{* * *} \\
(-3.34)\end{array}$ & $\begin{array}{c}0.0134^{* * *} \\
(5.29)\end{array}$ \\
\hline 15. $12: 15-12: 30$ & $\begin{array}{l}16.67 \\
(0.30)\end{array}$ & $\begin{array}{l}26.51 \\
(0.97)\end{array}$ & $\begin{array}{c}-0.0048 \\
(-1.50)\end{array}$ & $\begin{array}{c}-165.60^{* * *} \\
(-3.59)\end{array}$ & $\begin{array}{c}-73.01^{* * *} \\
(-3.15)\end{array}$ & $\begin{array}{c}0.0066^{* *} \\
(2.17)\end{array}$ & $\begin{array}{l}142.17 \\
(1.01)\end{array}$ & $\begin{array}{c}-26.35^{* * * *} \\
(-2.74)\end{array}$ & $\begin{array}{c}0.0190^{* * *} \\
(3.77)\end{array}$ & $\begin{array}{c}9.45 \\
(0.09)\end{array}$ & $\begin{array}{l}-11.88 \\
(-1.37)\end{array}$ & $\begin{array}{c}0.0084^{* * * *} \\
(3.31)\end{array}$ \\
\hline 16. $12: 30-12: 45$ & $\begin{array}{l}-52.80 \\
(-0.95)\end{array}$ & $\begin{array}{c}-4.79 \\
(-0.18)\end{array}$ & $\begin{array}{c}-0.0026 \\
(-0.82)\end{array}$ & $\begin{array}{c}-213.02^{* * *} \\
(-4.63)\end{array}$ & $\begin{array}{c}-113.49^{* * *} \\
(-4.90)\end{array}$ & $\begin{array}{c}0.0081^{* * *} \\
(2.66)\end{array}$ & $\begin{array}{l}30.09 \\
(0.21)\end{array}$ & $\begin{array}{c}-42.21^{\text {*** }} \\
(-4.39)\end{array}$ & $\begin{array}{c}0.0265^{* * *} \\
(5.27)\end{array}$ & $\begin{array}{l}-12.47 \\
(-0.11)\end{array}$ & $\begin{array}{c}-31.65^{* * *} \\
(-3.67)\end{array}$ & $\begin{array}{c}0.0106^{* * *} \\
(4.21)\end{array}$ \\
\hline 17. $12: 45-13: 00$ & $\begin{array}{l}37.86 \\
(0.68)\end{array}$ & $\begin{array}{c}6.68 \\
(0.24)\end{array}$ & $\begin{array}{c}-0.0026 \\
(-0.80)\end{array}$ & $\begin{array}{c}-95.13^{* *} \\
(-2.06)\end{array}$ & $\begin{array}{c}-56.68^{* *} \\
(-2.44)\end{array}$ & $\begin{array}{c}0.0008 \\
(0.24)\end{array}$ & $\begin{array}{c}123.99 \\
(0.88)\end{array}$ & $\begin{array}{c}-37.12^{* * * *} \\
(-3.85)\end{array}$ & $\begin{array}{c}0.0239^{* * * *} \\
(4.74)\end{array}$ & $\begin{array}{l}34.81 \\
(0.32)\end{array}$ & $\begin{array}{c}-15.28^{*} \\
(-1.76)\end{array}$ & $\begin{array}{c}0.0068^{* * *} \\
(2.67)\end{array}$ \\
\hline 18. $13: 00-13: 15$ & $\begin{array}{l}97.15^{*} \\
(1.74)\end{array}$ & $\begin{array}{l}30.12 \\
(1.10)\end{array}$ & $\begin{array}{l}-0.0016 \\
(-0.50)\end{array}$ & $\begin{array}{l}31.86 \\
(0.69)\end{array}$ & $\begin{array}{c}0.94 \\
(0.04)\end{array}$ & $\begin{array}{c}-0.0007 \\
(-0.24)\end{array}$ & $\begin{array}{c}361.89^{* * * *} \\
(2.56)\end{array}$ & $\begin{array}{c}9.41 \\
(0.98)\end{array}$ & $\begin{array}{c}0.0138^{* * *} \\
(2.74)\end{array}$ & $\begin{array}{l}123.85 \\
(1.14)\end{array}$ & $\begin{array}{c}3.79 \\
(0.44)\end{array}$ & $\begin{array}{c}0.0017 \\
(0.68)\end{array}$ \\
\hline 19. $13: 15-13: 30$ & $\begin{array}{c}-333.42^{* * *} \\
(-5.95)\end{array}$ & $\begin{array}{c}-164.84^{* * *} \\
(-6.03)\end{array}$ & $\begin{array}{c}0.0063^{* *} \\
(1.96)\end{array}$ & $\begin{array}{l}-89.07^{*} \\
(-1.93)\end{array}$ & $\begin{array}{l}-57.83^{* *} \\
(-2.48)\end{array}$ & $\begin{array}{c}0.0029 \\
(0.95)\end{array}$ & $\begin{array}{c}254.02^{*} \\
(1.80)\end{array}$ & $\begin{array}{c}70.92^{* * *} \\
(7.34)\end{array}$ & $\begin{array}{c}-0.0051 \\
(-1.01)\end{array}$ & $\begin{array}{c}-236.23^{* *} \\
(-2.17)\end{array}$ & $\begin{array}{c}-33.69^{* * *} \\
(-3.89)\end{array}$ & $\begin{array}{c}0.0081^{* * * *} \\
(3.22)\end{array}$ \\
\hline $\mathrm{C}$ & $\begin{array}{c}2272.27^{* * * *} \\
(182.53)\end{array}$ & $\begin{array}{l}807.00^{* * * *} \\
(132.77)\end{array}$ & $\begin{array}{l}0.7555^{* * * *} \\
(1055.38)\end{array}$ & $\begin{array}{c}2129.46^{* * * *} \\
(207.29)\end{array}$ & $\begin{array}{l}780.19^{* * *} \\
(150.82)\end{array}$ & $\begin{array}{l}0.7466^{* * *} \\
(1093.45)\end{array}$ & $\begin{array}{c}2800.14^{* * *} \\
(89.15)\end{array}$ & $\begin{array}{c}174.91^{\text {*** }} \\
(81.51)\end{array}$ & $\begin{array}{l}0.9066^{* * *} \\
(807.97)\end{array}$ & $\begin{array}{c}2615.02^{* * *} \\
(108.11)\end{array}$ & $\begin{array}{l}205.30^{* * *} \\
(106.56)\end{array}$ & $\begin{array}{l}0.9168^{* * * *} \\
(1630.38)\end{array}$ \\
\hline Observation & 10,042 & 10,042 & 10,042 & 10,042 & 10,042 & 10,042 & 10,042 & 10,042 & 10,042 & 10,042 & 10,042 & 10,042 \\
\hline $\begin{array}{l}\text { Adjusted R- } \\
\text { squared }\end{array}$ & 0.090 & 0.082 & 0.225 & 0.119 & 0.155 & 0.132 & 0.048 & 0.084 & 0.203 & 0.050 & 0.102 & 0.078 \\
\hline F-test & $50.88^{* * *}$ & $46.07^{* * *}$ & $146.51^{* * *}$ & $68.72^{* * *}$ & $93.27^{* * *}$ & $77.14^{* * *}$ & $26.14^{* * *}$ & $47.25^{* * *}$ & $128.82^{* * *}$ & $27.37^{* * *}$ & $58.28^{* * *}$ & $43.39^{* * *}$ \\
\hline
\end{tabular}

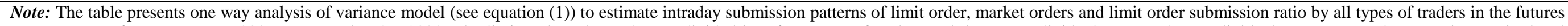

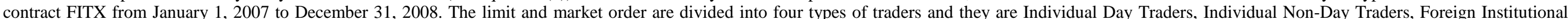

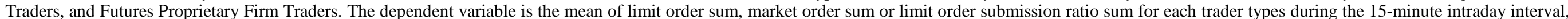

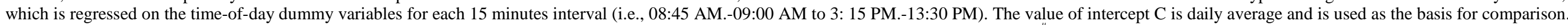

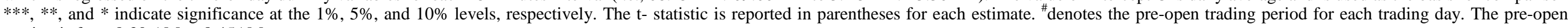
session is from 8:30 AM to 8:45AM. 
Table 4: Regression analysis of limit and market order size regression by trader type

\begin{tabular}{|c|c|c|c|c|c|c|c|c|}
\hline \multirow[t]{2}{*}{ Time Interval } & \multicolumn{2}{|c|}{ Individual Day Trader } & \multicolumn{2}{|c|}{ Individual Non Day Trader } & \multicolumn{2}{|c|}{ Foreign Institutional Traders } & \multicolumn{2}{|c|}{$\begin{array}{c}\text { Futures Proprietary Firm } \\
\text { Traders } \\
\end{array}$} \\
\hline & Limit & Market & Limit & Market & Limit & Market & Limit & Market \\
\hline $08: 30-08: 45^{\#}$ & $\begin{array}{l}-0.1170^{* * *} \\
(-12.40)\end{array}$ & $\begin{array}{c}0.0084 \\
(0.49)\end{array}$ & $\begin{array}{l}0.1954^{* * *} \\
(19.87)\end{array}$ & $\begin{array}{l}0.1300^{* * *} \\
(9.42)\end{array}$ & $\begin{array}{l}5.7214^{* * *} \\
(91.90)\end{array}$ & $\begin{array}{l}24.6161^{* * * *} \\
(71.05)\end{array}$ & $\begin{array}{l}3.3099^{* * *} \\
(190.26)\end{array}$ & $\begin{array}{l}3.1426^{* * * *} \\
(29.04)\end{array}$ \\
\hline 1. 08:45-09:00 & $\begin{array}{c}-0.0347^{* * * *} \\
(-5.25)\end{array}$ & $\begin{array}{l}-0.1662^{* * *} \\
(-22.77)\end{array}$ & $\begin{array}{l}-0.0902^{* * *} \\
(-14.01)\end{array}$ & $\begin{array}{c}-0.1687^{* * *} \\
(-23.80)\end{array}$ & $\begin{array}{l}0.0757^{* * *} \\
(6.26)\end{array}$ & $\begin{array}{c}1.7080^{* * *} \\
(18.96)\end{array}$ & $\begin{array}{c}0.2423^{* * *} \\
(49.43)\end{array}$ & $\begin{array}{c}0.1143^{* * *} \\
(3.09)\end{array}$ \\
\hline 2. 09:00-09:15 & $\begin{array}{l}0.1385^{* * *} \\
(22.66)\end{array}$ & $\begin{array}{l}0.0305^{* * *} \\
(5.08)\end{array}$ & $\begin{array}{l}-0.0895^{* * *} \\
(-12.96)\end{array}$ & $\begin{array}{c}-0.0740^{* * *} \\
(-9.76)\end{array}$ & $\begin{array}{c}-0.3852^{* * *} \\
(-39.84)\end{array}$ & $\begin{array}{c}-0.1752^{* *} \\
(-2.36)\end{array}$ & $\begin{array}{l}-0.0528^{* * *} \\
(-12.22)\end{array}$ & $\begin{array}{l}-0.3530^{* * *} \\
(-10.49)\end{array}$ \\
\hline 3. 09:15-09:30 & $\begin{array}{c}0.0402^{* * * *} \\
(6.57)\end{array}$ & $\begin{array}{c}0.0066 \\
(1.07)\end{array}$ & $\begin{array}{c}-0.0970^{* * *} \\
(-13.57)\end{array}$ & $\begin{array}{c}-0.0536^{* * *} \\
(-6.48)\end{array}$ & $\begin{array}{c}-0.3218^{* * *} \\
(-33.12)\end{array}$ & $\begin{array}{c}-0.8310^{* * *} \\
(-10.38)\end{array}$ & $\begin{array}{c}-0.1208^{* * *} \\
(-27.30)\end{array}$ & $\begin{array}{c}-0.1510^{* * * *} \\
(-3.98)\end{array}$ \\
\hline 4. 09:30-09:45 & $\begin{array}{c}0.0156^{* *} \\
(2.45)\end{array}$ & $\begin{array}{c}-0.0163^{* *} \\
(-2.53)\end{array}$ & $\begin{array}{c}-0.0675^{* * *} \\
(-9.01)\end{array}$ & $\begin{array}{c}-0.0571^{* * *} \\
(-6.36)\end{array}$ & $\begin{array}{l}-0.2670^{* * *} \\
(-26.42)\end{array}$ & $\begin{array}{c}-0.7203^{* * *} \\
(-8.19)\end{array}$ & $\begin{array}{c}-0.1442^{* * *} \\
(-31.45)\end{array}$ & $\begin{array}{c}-0.1114^{* * *} \\
(-2.68)\end{array}$ \\
\hline 5. 09:45-10:00 & $\begin{array}{c}0.0154^{* *} \\
(2.39)\end{array}$ & $\begin{array}{c}-0.0115^{*} \\
(-1.78)\end{array}$ & $\begin{array}{c}-0.0226^{* * *} \\
(-2.95)\end{array}$ & $\begin{array}{c}-0.0205^{* *} \\
(-2.25)\end{array}$ & $\begin{array}{c}-0.3376^{* * * *} \\
(-32.61)\end{array}$ & $\begin{array}{c}-0.9115^{* * *} \\
(-10.06)\end{array}$ & $\begin{array}{c}-0.1676^{* * * *} \\
(-35.79)\end{array}$ & $\begin{array}{c}-0.0289 \\
(-0.68)\end{array}$ \\
\hline 6. $10: 00-10: 15$ & $\begin{array}{c}-0.0345^{\text {*** }} \\
(-5.24)\end{array}$ & $\begin{array}{c}-0.0182^{* * *} \\
(-2.78)\end{array}$ & $\begin{array}{c}0.0031 \\
(0.40)\end{array}$ & $\begin{array}{c}-0.0062 \\
(-0.65)\end{array}$ & $\begin{array}{c}-0.3094^{* * * *} \\
(-28.78)\end{array}$ & $\begin{array}{c}-0.9704^{* * *} \\
(-10.44)\end{array}$ & $\begin{array}{c}-0.2368^{* * *} \\
(-49.47)\end{array}$ & $\begin{array}{c}-0.0522 \\
(-1.18)\end{array}$ \\
\hline 7. $10: 15-10: 30$ & $\begin{array}{c}-0.0635^{* * * *} \\
(-9.49)\end{array}$ & $\begin{array}{c}-0.0367^{* * * *} \\
(-5.52)\end{array}$ & $\begin{array}{c}-0.0056 \\
(-0.69)\end{array}$ & $\begin{array}{r}-0.0188^{*} \\
(-1.90)\end{array}$ & $\begin{array}{c}-0.3653^{* * *} \\
(-32.77)\end{array}$ & $\begin{array}{c}-1.3504^{* * * *} \\
(-14.21)\end{array}$ & $\begin{array}{c}-0.2497^{* * * *} \\
(-51.41)\end{array}$ & $\begin{array}{c}-0.2025^{* * * *} \\
(-4.47)\end{array}$ \\
\hline 8. $10: 30-10: 45$ & $\begin{array}{c}-0.1311^{* * * *} \\
(-19.03)\end{array}$ & $\begin{array}{c}-0.0593^{* * *} \\
(-8.59)\end{array}$ & $\begin{array}{c}-0.0579^{* * *} \\
(-6.88)\end{array}$ & $\begin{array}{c}-0.0123 \\
(-1.19)\end{array}$ & $\begin{array}{c}-0.5853^{* * *} \\
(-52.52)\end{array}$ & $\begin{array}{c}-1.3928^{* * * *} \\
(-14.20)\end{array}$ & $\begin{array}{c}-0.2643^{* * *} \\
(-53.62)\end{array}$ & $\begin{array}{c}-0.2525^{* * * *} \\
(-5.17)\end{array}$ \\
\hline 9. $10: 45-11: 00$ & $\begin{array}{c}-0.1473^{* * * *} \\
(-21.51)\end{array}$ & $\begin{array}{c}-0.0304^{* * * *} \\
(-4.44)\end{array}$ & $\begin{array}{c}-0.0106 \\
(-1.27)\end{array}$ & $\begin{array}{c}-0.0077 \\
(-0.76)\end{array}$ & $\begin{array}{c}-0.5099^{* * *} \\
(-45.37)\end{array}$ & $\begin{array}{c}-1.6362^{* * *} \\
(-16.61)\end{array}$ & $\begin{array}{c}-0.2198^{* * * *} \\
(-44.90)\end{array}$ & $\begin{array}{c}-0.0565 \\
(-1.19)\end{array}$ \\
\hline 10. $11: 00-11: 15$ & $\begin{array}{c}-0.1186^{* * * *} \\
(-16.81)\end{array}$ & $\begin{array}{c}-0.0236^{* * *} \\
(-3.32)\end{array}$ & $\begin{array}{c}0.0039 \\
(0.45)\end{array}$ & $\begin{array}{c}0.0086 \\
(0.81)\end{array}$ & $\begin{array}{c}-0.5268^{* * *} \\
(-45.62)\end{array}$ & $\begin{array}{c}-1.2922^{* * * *} \\
(-12.88)\end{array}$ & $\begin{array}{c}-0.2321^{* * * *} \\
(-46.04)\end{array}$ & $\begin{array}{c}-0.1532^{* * *} \\
(-3.08)\end{array}$ \\
\hline 11. $11: 15-11: 30$ & $\begin{array}{c}-0.0905^{* * * *} \\
(-13.05)\end{array}$ & $\begin{array}{c}-0.0025 \\
(-0.36)\end{array}$ & $\begin{array}{c}0.0346^{* * *} \\
(4.09)\end{array}$ & $\begin{array}{c}0.0374^{* * *} \\
(3.67)\end{array}$ & $\begin{array}{c}-0.5282^{* * *} \\
(-46.02)\end{array}$ & $\begin{array}{c}-1.6840^{* * * *} \\
(-17.82)\end{array}$ & $\begin{array}{c}-0.2288^{* * * *} \\
(-46.42)\end{array}$ & $\begin{array}{c}-0.1734^{* * *} \\
(-3.84)\end{array}$ \\
\hline 12. $11: 30-11: 45$ & $\begin{array}{c}-0.0232^{* * * *} \\
(-3.41)\end{array}$ & $\begin{array}{c}0.0096 \\
(1.42)\end{array}$ & $\begin{array}{c}0.0164^{* *} \\
(1.96)\end{array}$ & $\begin{array}{c}0.0419^{* * *} \\
(4.15)\end{array}$ & $\begin{array}{c}-0.4300^{* * *} \\
(-38.15)\end{array}$ & $\begin{array}{c}-1.5553^{* * *} \\
(-16.45)\end{array}$ & $\begin{array}{c}-0.2023^{* * *} \\
(-41.67)\end{array}$ & $\begin{array}{c}-0.7042^{* * *} \\
(-17.25)\end{array}$ \\
\hline 13. $11: 45-12: 00$ & $\begin{array}{c}-0.0313^{* * * *} \\
(-4.57) \\
\end{array}$ & $\begin{array}{c}0.0271^{\text {*** }} \\
(3.98)\end{array}$ & $\begin{array}{c}-0.0252^{* * *} \\
(-3.03)\end{array}$ & $\begin{array}{c}0.0482^{* * *} \\
(4.82)\end{array}$ & $\begin{array}{c}-0.3033^{* * *} \\
(-27.03)\end{array}$ & $\begin{array}{c}-1.7834^{* * *} \\
(-18.87)\end{array}$ & $\begin{array}{c}-0.2335^{* * * *} \\
(-47.89)\end{array}$ & $\begin{array}{c}-0.4007^{* * *} \\
(-9.55)\end{array}$ \\
\hline
\end{tabular}


Table 4 (Continue):

\begin{tabular}{|c|c|c|c|c|c|c|c|c|}
\hline \multirow{2}{*}{ Time Interval } & \multicolumn{2}{|c|}{ Individual Day Trader } & \multicolumn{2}{|c|}{ Individual Non Day Trader } & \multicolumn{2}{|c|}{ Foreign Institutional Traders } & \multicolumn{2}{|c|}{$\begin{array}{c}\text { Futures Proprietary Firm } \\
\text { Traders }\end{array}$} \\
\hline & Limit & Market & Limit & Market & Limit & Market & Limit & Market \\
\hline 14. $12: 00-12: 15$ & $\begin{array}{c}0.0078 \\
(1.11)\end{array}$ & $\begin{array}{l}0.0490^{* * *} \\
(7.05)\end{array}$ & $\begin{array}{c}-0.0618^{* * *} \\
(-7.25)\end{array}$ & $\begin{array}{c}0.0364^{* * *} \\
(3.56)\end{array}$ & $\begin{array}{l}-0.2338^{* * *} \\
(-21.01)\end{array}$ & $\begin{array}{l}-1.8204^{* * *} \\
(-19.36)\end{array}$ & $\begin{array}{c}-0.2815^{* * *} \\
(-57.56)\end{array}$ & $\begin{array}{c}-0.1933^{* * * *} \\
(-4.15)\end{array}$ \\
\hline 15. $12: 15-12: 30$ & $\begin{array}{l}0.0489^{* * *} \\
(7.03)\end{array}$ & $\begin{array}{l}0.0459^{* * *} \\
(6.65)\end{array}$ & $\begin{array}{l}0.0179^{* *} \\
(2.14)\end{array}$ & $\begin{array}{l}0.0411^{* * *} \\
(4.14)\end{array}$ & $\begin{array}{l}-0.1981^{* * *} \\
(-17.92)\end{array}$ & $\begin{array}{l}-1.9944^{* * * *} \\
(-22.33)\end{array}$ & $\begin{array}{c}-0.2556^{* * *} \\
(-53.00)\end{array}$ & $\begin{array}{c}-0.0222 \\
(-0.49)\end{array}$ \\
\hline 16. $12: 30-12: 45$ & $\begin{array}{l}0.0597^{* * *} \\
(8.45)\end{array}$ & $\begin{array}{l}0.0491^{* * *} \\
(6.99)\end{array}$ & $\begin{array}{c}0.0167^{* *} \\
(1.97)\end{array}$ & $\begin{array}{c}0.0149 \\
(1.47)\end{array}$ & $\begin{array}{l}-0.2677^{* * *} \\
(-23.94)\end{array}$ & $\begin{array}{l}-2.0648^{* * *} \\
(-22.10)\end{array}$ & $\begin{array}{c}-0.1987^{* * *} \\
(-40.66)\end{array}$ & $\begin{array}{c}-0.1621^{* * * *} \\
(-3.44)\end{array}$ \\
\hline 17. $12: 45-13: 00$ & $\begin{array}{l}0.0915^{* * *} \\
(13.11)\end{array}$ & $\begin{array}{l}0.0609^{* * *} \\
(8.67)\end{array}$ & $\begin{array}{c}0.0297^{* * *} \\
(3.61)\end{array}$ & $\begin{array}{c}0.0374^{* * *} \\
(3.82)\end{array}$ & $\begin{array}{l}-0.2730^{* * *} \\
(-24.73)\end{array}$ & $\begin{array}{l}-2.1274^{* * *} \\
(-23.30)\end{array}$ & $\begin{array}{c}-0.2054^{* * *} \\
(-42.33)\end{array}$ & $\begin{array}{c}-0.0548 \\
(-1.20)\end{array}$ \\
\hline 18. $13: 00-13: 15$ & $\begin{array}{c}0.1281^{* * * *} \\
(18.42)\end{array}$ & $\begin{array}{l}0.0607^{* * * *} \\
(8.77)\end{array}$ & $\begin{array}{c}0.0412^{* * * *} \\
(5.13)\end{array}$ & $\begin{array}{l}0.0289^{* * * *} \\
(3.08)\end{array}$ & $\begin{array}{c}-0.1729^{* * *} \\
(-16.06)\end{array}$ & $\begin{array}{c}-2.3978^{* * *} \\
(-30.74)\end{array}$ & $\begin{array}{c}-0.2105^{* * *} \\
(-44.04)\end{array}$ & $\begin{array}{c}-0.0644 \\
(-1.48)\end{array}$ \\
\hline 19. $13: 15-13: 30$ & $\begin{array}{l}0.1063^{* * *} \\
(13.96)\end{array}$ & $\begin{array}{c}0.0076 \\
(0.98)\end{array}$ & $\begin{array}{l}0.0516^{* * * *} \\
(6.23)\end{array}$ & $\begin{array}{c}-0.0033 \\
(-0.34)\end{array}$ & $\begin{array}{l}0.0245^{* * *} \\
(2.20)\end{array}$ & $\begin{array}{c}-1.9318^{* * * *} \\
(-26.84)\end{array}$ & $\begin{array}{c}-0.2189^{* * * *} \\
(-42.95)\end{array}$ & $\begin{array}{c}-0.0391 \\
(-0.81)\end{array}$ \\
\hline $\mathrm{C}$ & $\begin{array}{l}2.2791^{* * *} \\
(1455.77)\end{array}$ & $\begin{array}{l}1.9928^{* * *} \\
(1165.16)\end{array}$ & $\begin{array}{l}2.4798^{* * *} \\
(1367.98)\end{array}$ & $\begin{array}{l}2.3579^{* * *} \\
(1083.70)\end{array}$ & $\begin{array}{l}5.4160^{* * *} \\
(1395.77)\end{array}$ & $\begin{array}{l}6.8632^{* * *} \\
(265.65)\end{array}$ & $\begin{array}{l}2.6302^{* * * *} \\
(1944.13)\end{array}$ & $\begin{array}{l}4.2399^{* * *} \\
(389.84)\end{array}$ \\
\hline Observation & $10,039,866$ & $4,078,962$ & $8,690,712$ & $3,374,647$ & $5,489,755$ & 305,877 & $10,624,149$ & 511,533 \\
\hline $\begin{array}{c}\text { Adjusted R-squared } \\
\text { F-test }\end{array}$ & $\begin{array}{c}0.0003 \\
157.68^{* * *}\end{array}$ & $\begin{array}{c}0.0002 \\
48.71^{* * * *}\end{array}$ & $\begin{array}{c}0.0002 \\
70.26^{* * *}\end{array}$ & $\begin{array}{c}0.0003 \\
44.43^{* * *}\end{array}$ & $\begin{array}{c}0.0026 \\
710.04^{* * *}\end{array}$ & $\begin{array}{c}0.0239 \\
376.18^{* * *}\end{array}$ & $\begin{array}{c}0.0048 \\
2544.45^{* * *}\end{array}$ & $\begin{array}{c}0.0023 \\
59.72^{* * *}\end{array}$ \\
\hline
\end{tabular}

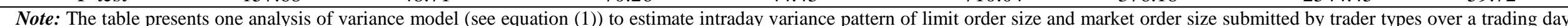

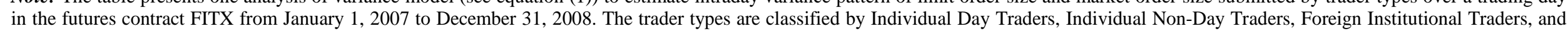

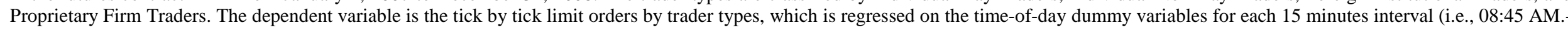

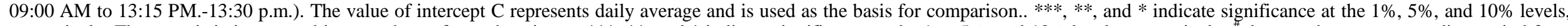

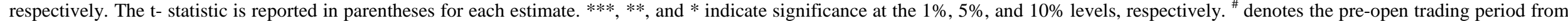
8:30 AM to 8:45AM.for each trading day. 
Table 5: Regression analysis on the influences of market conditions on liquidity provision by trader types

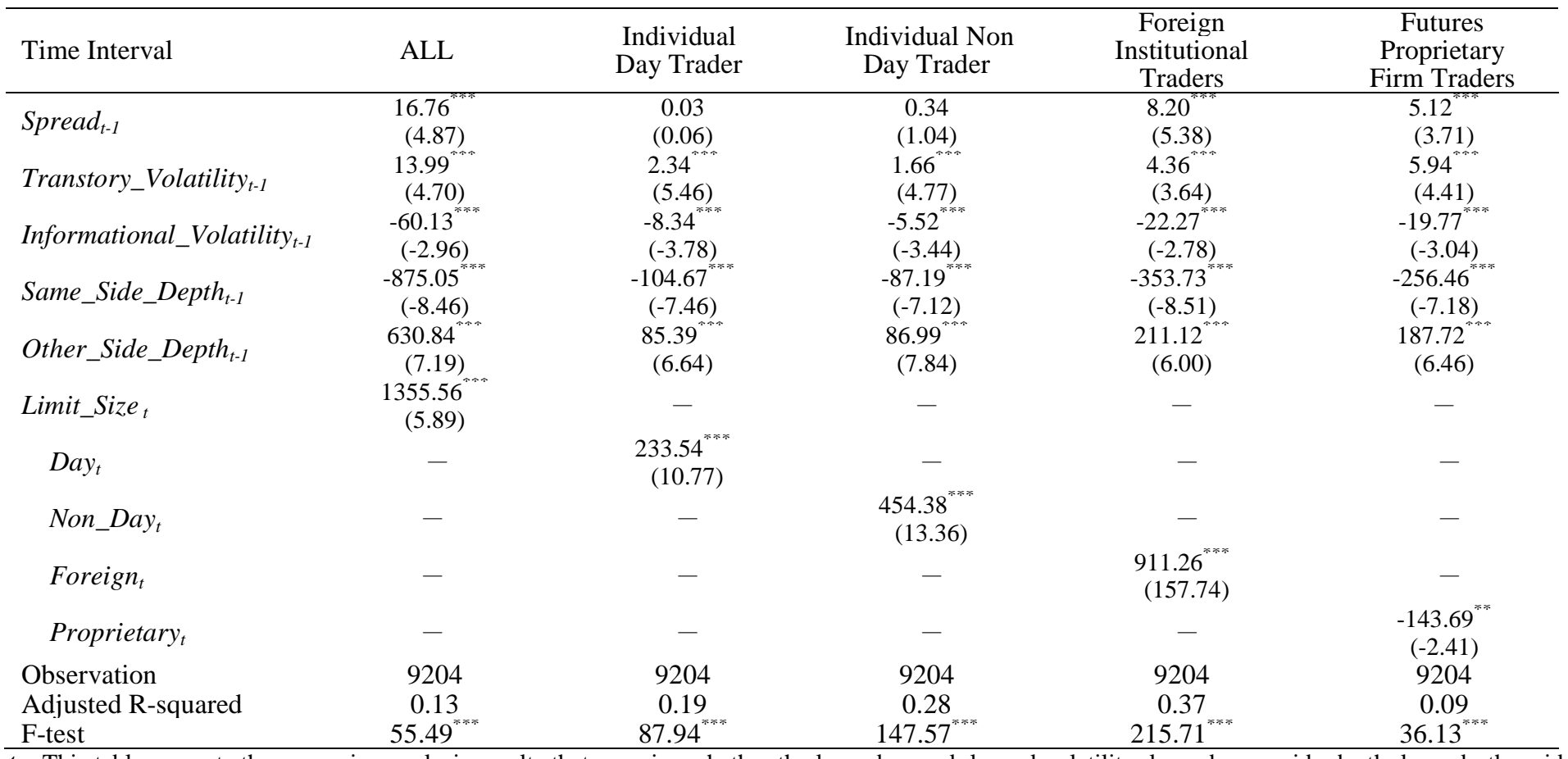

Note: This table presents the regression analysis results that examine whether the lagged spread, lagged volatility, lagged same side depth, lagged other side depth and limit order size by the trader type variables affect limit orders in the futures contract FITX. The regression analysis model is specified as follows,

$$
\begin{aligned}
\text { NLM }_{t}= & \alpha+\beta_{1} \text { Spread }_{t-1}+\beta_{2} \text { Transtory }_{-} \text {Volatility }_{t-1}+\beta_{3} \text { Informational_Volatility }_{t-1}+ \\
& \beta_{4} \text { Same_Side_Depth }_{t-1}+\beta_{5} \text { Other_Side_Depth }_{t-1}+\beta_{6} \text { Limit }_{-} \text {Size }_{t}+\sum_{j=1}^{19} \beta_{7, j} D_{j}+\varepsilon_{t}
\end{aligned}
$$

The dependent variable $N L M_{t}$ is equal to the sum of limit orders minus market orders and marketable limit orders for each trader types during 15 minutes interval. The trader types are classified by Individual Day Traders, Individual Non-Day Traders, Foreign Institutional Traders, and Proprietary Firm Traders. Spread $t_{t-1}$ is the average of dollar quote spread during time interval t-1; Transtory_Volatility t-1 $_{-}$denotes transitory volatility lagged one period; Informational_Volatility $t_{t-1}$ represents informational volatility lagged one period; Same_Side_Depth t-1 $_{-}$ (Other_Side_Deptht-1) is measured as the average number of limit orders at the best bid (ask) just prior to a buy order's submission, and as the average number of limit order at the ask (bid) just prior to a sell order's submission during time interval t-1; Limit_Size $_{t}$ is the average of limit orders during time interval $\mathrm{t}$ for all traders, Individual Day Traders, Individual Non Day Traders, Foreign Institutional Traders, and Proprietary Firm Traders; $D_{i}$ is the time-of-day dummy variables for each 15 minutes interval (i.e., 08:45 a.m.-09:00 a.m.,...,13:15 p.m.-13:30 p.m.). The specification of $D_{j}$ is discussed in equation (1). To save the space, we do not report the dummy variables results. The t-statistic is reported in parentheses for each estimate. $* * *, * *$, and $*$ indicate significance at the $1 \%, 5 \%$, and $10 \%$ levels, respectively. 
Table 6: Elasticity of net limit order submissions with respect to market condition variables and limit order size.

\begin{tabular}{|c|c|c|c|c|c|}
\hline Variables & ALL & $\begin{array}{c}\text { Individual Day } \\
\text { Trader }\end{array}$ & $\begin{array}{l}\text { Individual Non } \\
\text { Day Trader }\end{array}$ & $\begin{array}{c}\text { Foreign } \\
\text { Institutional } \\
\text { Traders }\end{array}$ & $\begin{array}{c}\text { Futures } \\
\text { Proprietary } \\
\text { Firm Traders }\end{array}$ \\
\hline Spread $_{t-1}$ & 0.69 & 0.01 & 0.08 & 0.99 & 0.69 \\
\hline Transtory_Volatility $_{t-1}$ & 0.12 & 0.11 & 0.09 & 0.11 & 0.17 \\
\hline Informational_Volatility ${ }_{t-1}$ & -0.15 & -0.12 & -0.08 & -0.17 & -0.17 \\
\hline Same_Side_Depth $h_{t-1}$ & -1.05 & -0.68 & -0.62 & -1.24 & -1.00 \\
\hline Other_Side_Depth ${ }_{t-1}$ & 0.77 & 0.57 & 0.64 & 0.76 & 0.75 \\
\hline Limit_Size $_{t}$ & 0.50 & - & - & - & - \\
\hline Day $_{t}$ & - & 0.40 & - & - & - \\
\hline Non_Day $y_{t}$ & - & - & 0.85 & - & - \\
\hline Foreign $_{t}$ & - & - & - & 1.58 & - \\
\hline Proprietary $_{t}$ & - & - & - & - & -0.18 \\
\hline
\end{tabular}

Note: This table presents the estimates of the elasticity of Spread ${ }_{t-1}$, Transitory_Volatility $_{t-1}$, Informational_Volatility $_{t-1}$, Same Side Depth $t-1$, Other Side Depth ${ }_{t-1}$, and Limit Order Size from regression model on the influences of the market conditions on liquidity provision by trader type( see Table 5). The elasticity is measured as each regression coefficient multiplies the average of independent variable and divides by the average of dependent variable. The trader types are classified by Individual Day Traders, Individual Non-Day Traders, Foreign Institutional Traders, and Proprietary Futures Firm Traders. The regression model is specified as follows,

$$
\begin{aligned}
N_{L M}= & \alpha+\beta_{1} \text { Spread }_{t-1}+\beta_{2} \text { Transtory }_{-} \text {Volatility }_{t-1}+\beta_{3} \text { Informational }_{-} \text {Volatility }_{t-1}+ \\
& \beta_{4} \text { Same_Side_Depth }_{t-1}+\beta_{5} \text { Other_Side_Depth } \text { St-1 }_{-}+\beta_{6} \text { Limit }_{-} \text {Size }_{t}+\sum_{j=1}^{19} \beta_{7, j} D_{j}+\varepsilon_{t}
\end{aligned}
$$

The dependent variable, $N L M_{t}$ is equal to the sum of limit orders minus market orders and marketable limit orders for each trader types during 15 minutes interval. Spread $t_{t-1}$ is the average of dollar quote spread during time interval t-1; Transtory_Volatility $t_{t-1}$ denotes transitory volatility lagged one; Informational_Volatility $y_{t-1}$ represents informational volatility lagged one period; Same_Side_Depth ${ }_{t-1}\left(\right.$ Other_Side_Depth $\left.{ }_{t-1}\right)$ is measured as the average number of limit orders at the bid (ask) just prior to a buy order's submission, and as the average number of limit orders at the ask (bid) just prior to a sell order's submission during time interval t-1; Limit_Size is the average of limit orders during time interval $\mathrm{t}$ for all traders, Individual day Traders, Individual non-day Traders, Foreign institutional traders, and Proprietary futures Firm Traders respectively; $D_{j}$ is the time-of-day dummy variables for each 15 minutes interval (i.e., 08:45 a.m.-09:00 a.m.,...,13:15 p.m.-13:30 p.m.). The specification of $D_{j}$ is discussed in equation (1). To save the space, we do not report the dummy variables results. The t-statistic is reported in parentheses for each estimate. $* * * * *$, and $*$ indicate significance at the $1 \%, 5 \%$, and $10 \%$ levels, respectively. 
Table 7: Regression results on the influences of market conditions on liquidity provision by trader types on 30 minutes interval

\begin{tabular}{|c|c|c|c|c|c|}
\hline Time Interval & ALL & $\begin{array}{l}\text { Individual } \\
\text { Day Trader }\end{array}$ & $\begin{array}{c}\text { Individual Non } \\
\text { Day Trader }\end{array}$ & $\begin{array}{c}\text { Foreign } \\
\text { Institutional } \\
\text { Traders }\end{array}$ & $\begin{array}{c}\text { Futures } \\
\text { Proprietary } \\
\text { Firm Traders }\end{array}$ \\
\hline Spread $_{t-1}$ & $\begin{array}{l}38.15 \\
(7.80)\end{array}$ & $\begin{array}{c}0.92 \\
(1.29)\end{array}$ & $\begin{array}{l}1.52^{N, * n} \\
(2.76)\end{array}$ & $\begin{array}{c}18.86 \\
(8.05)\end{array}$ & $\begin{array}{l}9.50 \% \\
(4.35)\end{array}$ \\
\hline Transtory_Volatility $_{t-1}$ & $\begin{array}{c}48.27^{\cdots \cdots} \\
(9.75)\end{array}$ & $\begin{array}{l}6.38^{\circ} \\
(8.90)\end{array}$ & $\begin{array}{c}4.61^{1+n} \\
(8.34)\end{array}$ & $\begin{array}{c}17.86^{-m} \\
(7.51)\end{array}$ & $\begin{array}{c}17.39^{\cdots+\pi} \\
(7.88)\end{array}$ \\
\hline Informational_Volatility $_{t-1}$ & $\begin{array}{c}-190.82^{-11.89} \\
(-11.89)\end{array}$ & $\begin{array}{l}-25.67^{\cdots+\pi} \\
(-11.08)\end{array}$ & $\begin{array}{c}-16.09^{\operatorname{nin}} \\
(-9.02)\end{array}$ & $\begin{array}{l}-78.63^{\operatorname{man}} \\
(-10.27)\end{array}$ & $\begin{array}{c}-52.89^{\cdots n-1} \\
(-7.34)\end{array}$ \\
\hline Other_Side_Depth1-5 $5_{t-1}$ & $\begin{array}{c}330.86^{N \pi} \\
(7.22)\end{array}$ & $\begin{array}{c}22.74^{-1 n} \\
(3.43)\end{array}$ & $\begin{array}{c}31.20 \\
(6.11)\end{array}$ & $\begin{array}{l}159.14^{\ldots \ldots \pi} \\
(7.26)\end{array}$ & $\begin{array}{c}79.88^{\cdots n} \\
(3.88)\end{array}$ \\
\hline Limit_Size $_{t}$ & $\begin{array}{c}1271.11 \\
(5.52)\end{array}$ & - & - & - & - \\
\hline $\operatorname{Day}_{t}$ & (0.02) & $\begin{array}{c}383.89^{* * *} \\
(18.73)\end{array}$ & - & - & - \\
\hline Observation & 4422 & 4422 & 4422 & 4422 & 4422 \\
\hline Adjusted R-squared & 0.12 & 0.18 & 0.28 & 0.38 & 0.10 \\
\hline F-test & $41.94^{\pi \cdots *}$ & $63.36^{* * * \pi}$ & $112.22^{* \pi *}$ & $178.56^{\text {***is }}$ & $35.32^{* * * \pi}$ \\
\hline
\end{tabular}

Note: This table presents the robustness test on regression results by trader type categories in the futures contract FITX on thirty minute interval. The regression model is specified as follows,

$$
\begin{aligned}
& N L M_{t}=\alpha+\beta_{1} \text { Spread }_{t-1}+\beta_{2} \text { Transtory _ Volatility }_{t-1}+\beta_{3} \text { Informational_Volatility }_{t-1}+ \\
& \beta_{4} \text { Same_Side_Depth1- } 5_{t-1}+\beta_{5} \text { Other_Side_Depth1- } 5_{t-1}+\beta_{6} \text { Limit }- \text { Size } e_{t}+\sum_{j=1}^{19} \beta_{7, j} D_{j}+\varepsilon_{t}
\end{aligned}
$$

The dependent variable $N L M_{t}$ is equal to the sum of limit orders minus market orders and marketable limit orders for each trader types during 30 minutes interval. The trader types are classified by Individual Day Traders, Individual Non-Day Traders, Foreign Institutional Traders, and Proprietary Firm Traders. Spread $t_{t-1}$ is the average of dollar quote spread during time interval t-1; Transtory_Volatility ${ }_{t-1}$ denotes transitory volatility lagged one period; Informational_Volatility ${ }_{t-1}$ represents informational volatility lagged one period; Same_Side_Depth1$5_{t-1}\left(\right.$ Other_Side_Depth1-5 $5_{t-1}$ ) is measured as the average number of limit orders at the bid 1 to 5 (ask 1 to 5) just prior to a buy order's submission, and as the average number of limit orders at the ask 1 to 5 (bid 1 to 5) just prior to a sell order's submission during time interval $\mathrm{t}-1$; Limit_Size is the average of limit orders during time interval $\mathrm{t}$ for all traders, Individual day traders, Individual non- day traders, Foreign institutional traders, and Futures proprietary firm Traders respectively; $D_{j}$ is the time-of-day dummy variables for each 15 minutes interval (i.e., 08:45 a.m.-09:00 a.m. to 3:15 p.m.-13:30 p.m. ). The specification of $D_{j}$ is discussed in equation (1). To save the space, we do not report the dummy variables results. The t-statistic is reported in parentheses for each estimate. $* * *, * *$, and $*$ indicate significance at the $1 \%, 5 \%$, and $10 \%$ levels, respectively. 


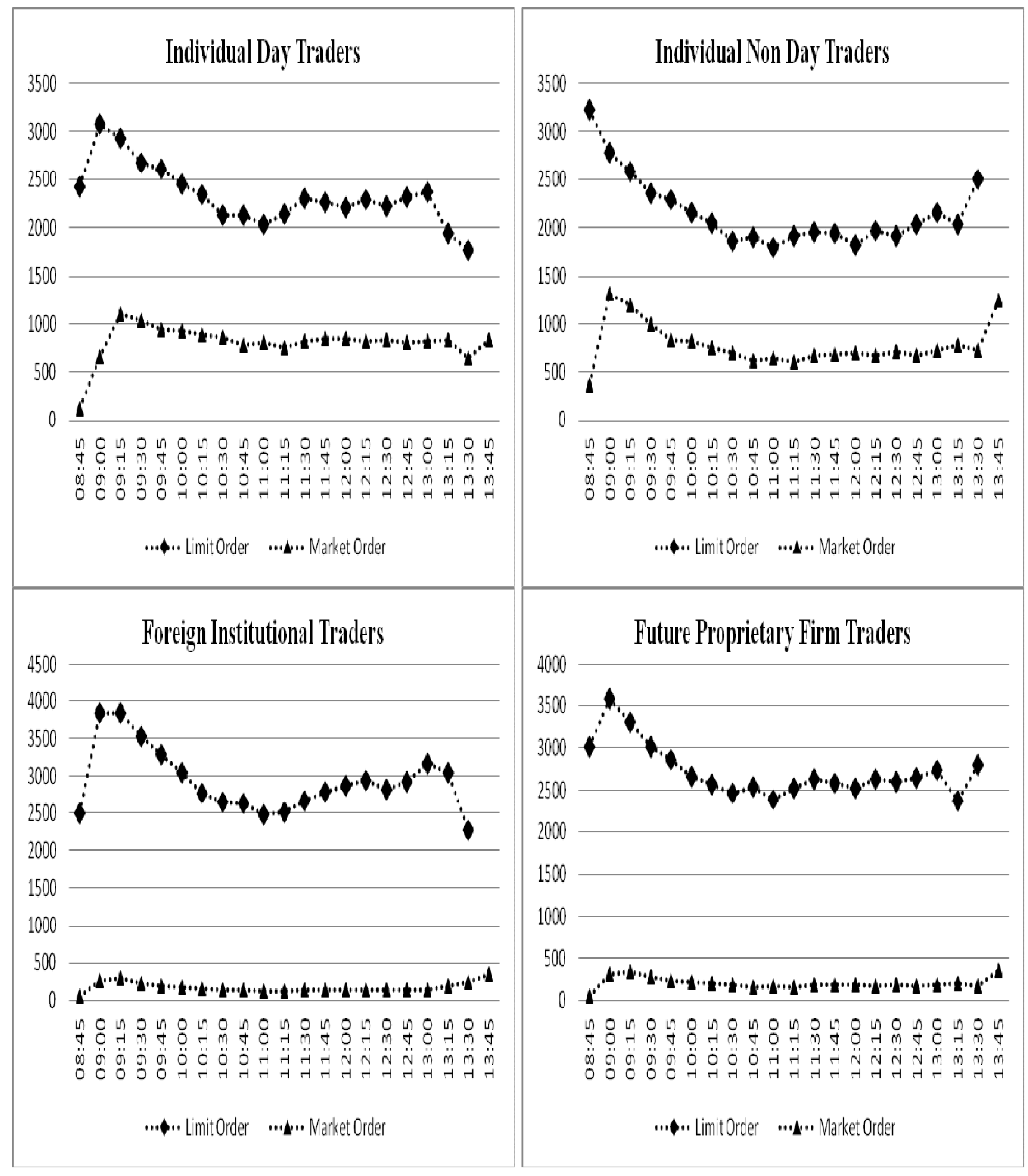

Figure 1: Intraday average numbers of limit and market order submission by four type of traders. The graph depicts the average number of orders submitted during the 15-min intervals of each trading day for the futures contract FITX from January 1, 2007 to December 31, 2008. The limit and market order are divided into four types of traders. They are Individual Day Traders, Individual Non-Day Traders, Foreign Institutional Traders, and Futures Proprietary Firm Traders. 


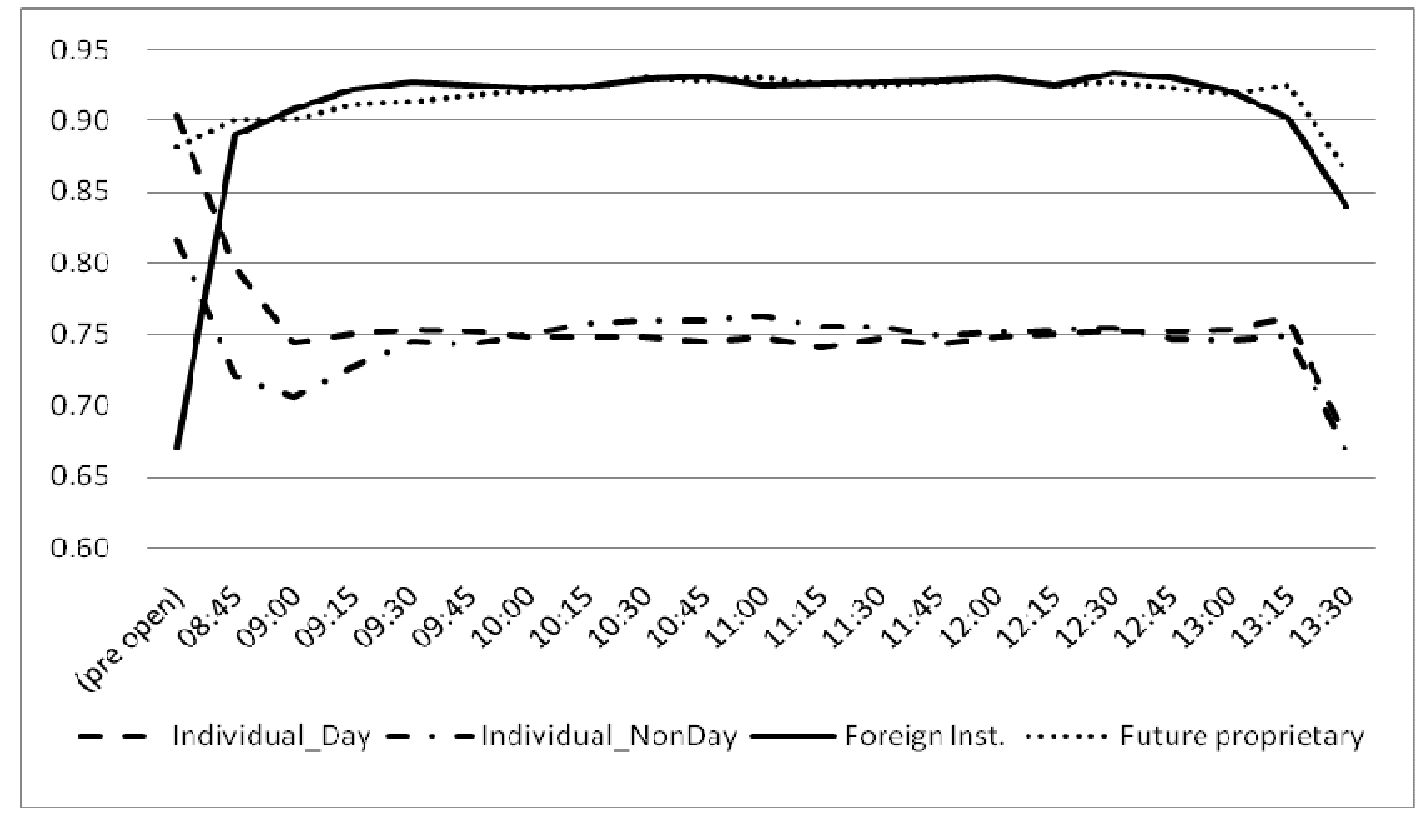

Figure 2(a): The intraday -day patterns of limit order submission ratios by trader types during full sample period (January 2007 to December 2008).

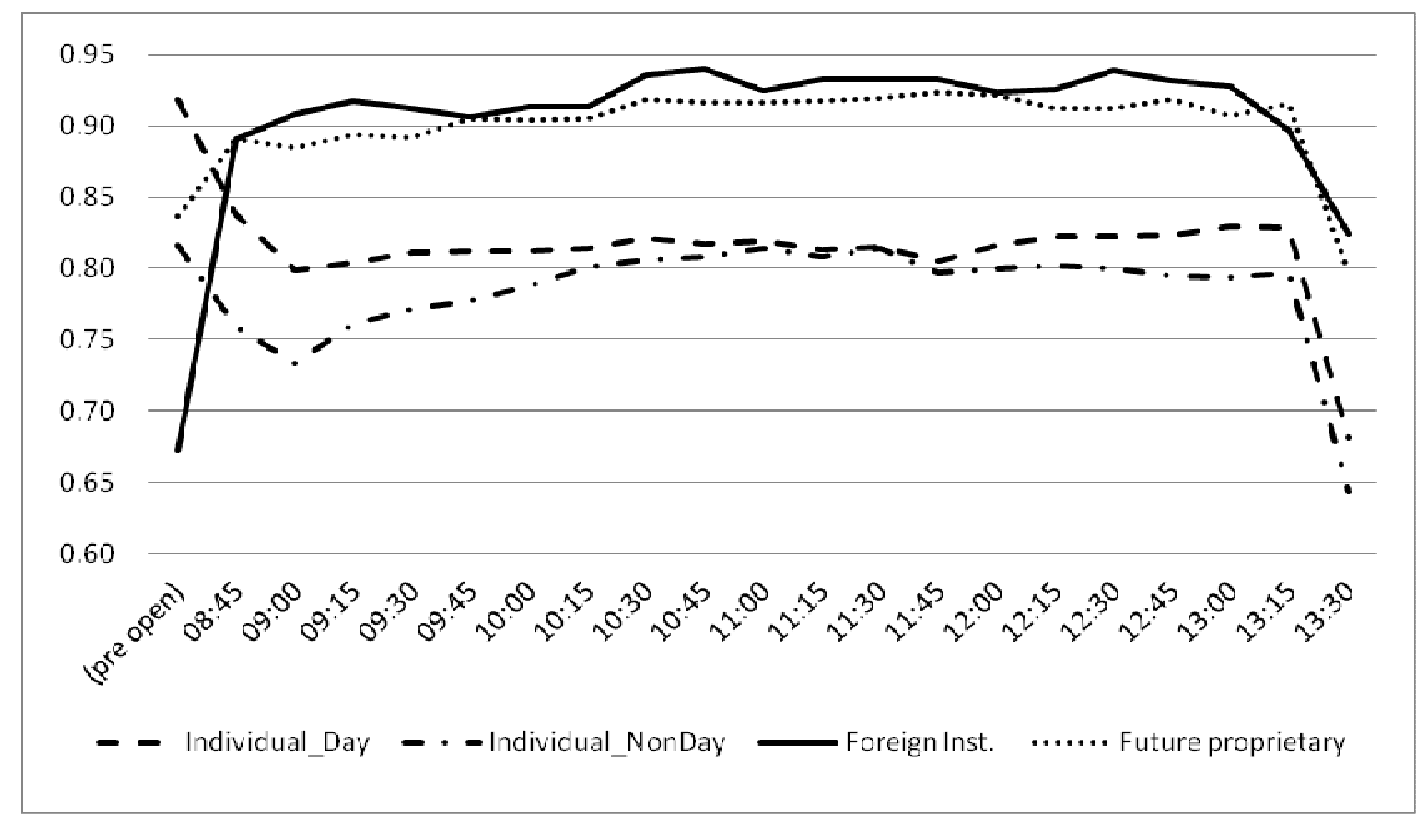

Figure 2 (b): The intraday -day patterns of limit order submission ratios by trader types in the pre financial crises period (January 2007 to July 2007).

Figure 2 (a) and (b) depict the means of limit order submission ratios during the 15-min intervals of each trading day for the futures contract FITX for full sample period and pre-global financial crisis period respectively. The pre-open session is from 8:30 AM to 8:45AM. Submission ratio is defined as the ratio of the number of limit order to the sum of his limit and market orders during each 15-minute interval. The four types of traders are: Individual day traders, Individual non-day traders, Foreign institutional traders, and Futures proprietary firm traders. 


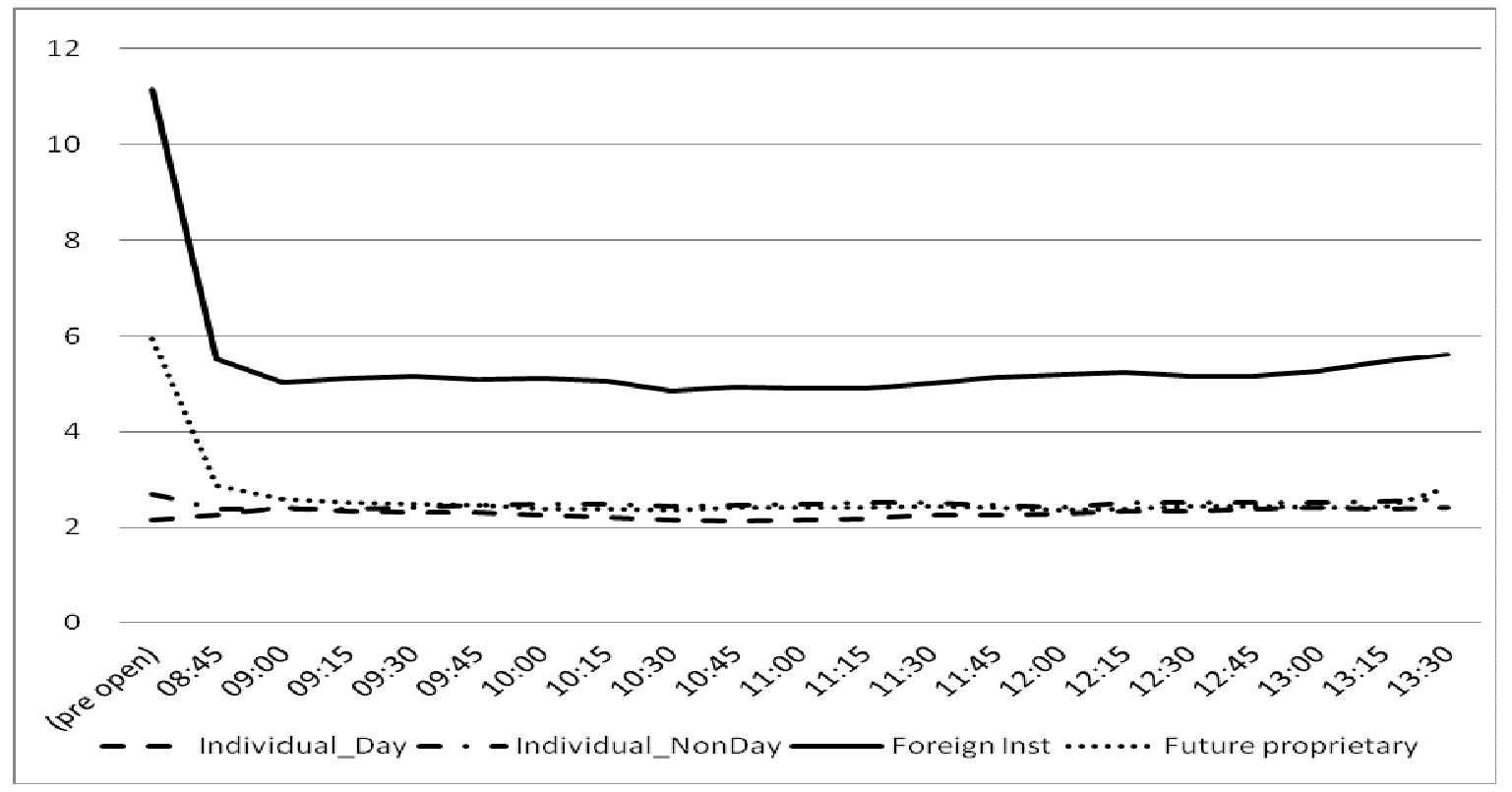

Figure 3a: The intra-day patterns of the size of limit orders by trader types

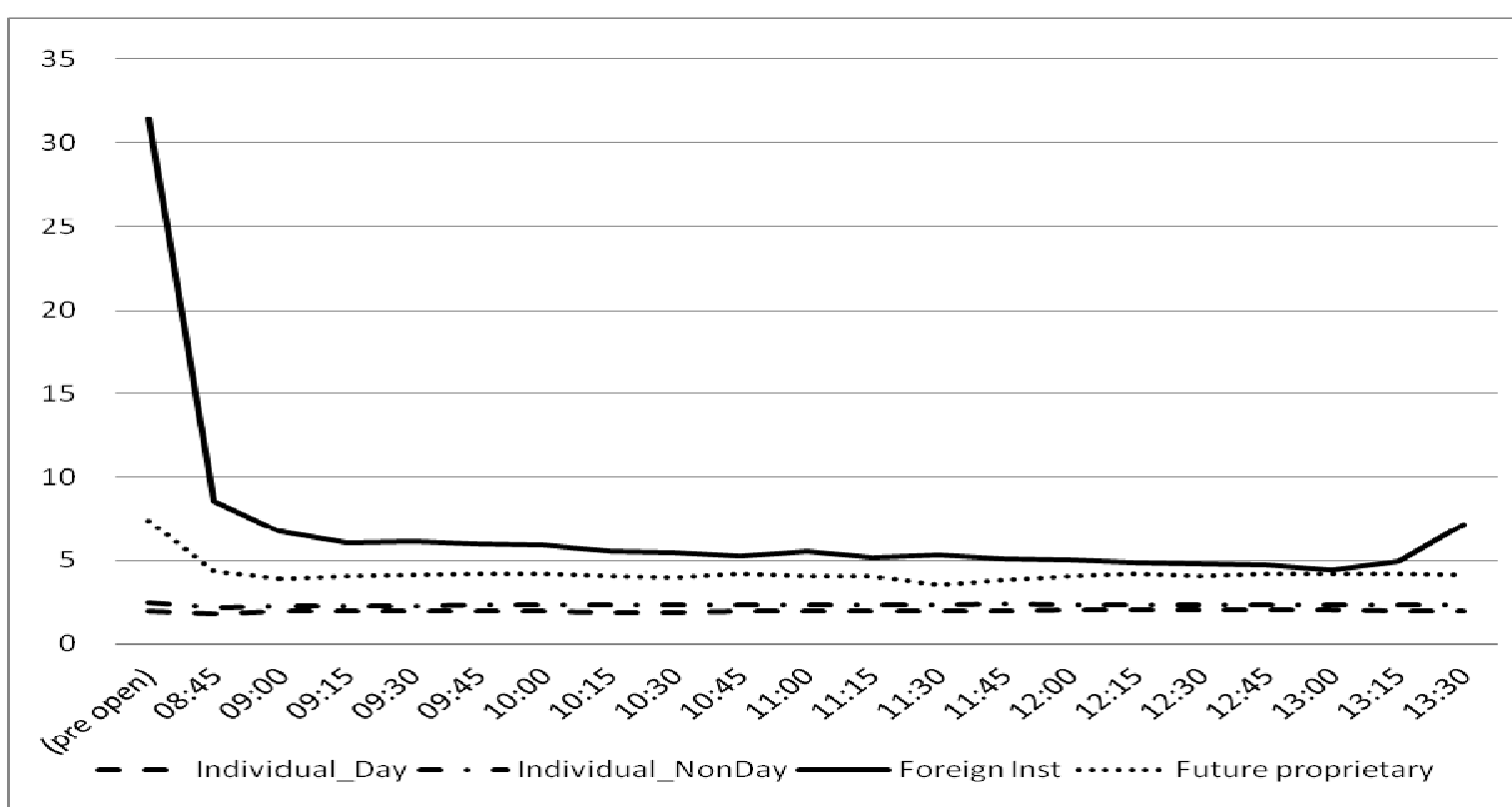

Figure 3b: The intra-day patterns of the size of market orders by trader types.

Figure 3: plots the means of order sizes of limit and market order by trader type during the 15-min intervals of each trading day for the futures contract FITX from January 1, 2007 to December 31, 2008. The pre-open session is from 8:30 AM to 8:45AM.The four trader types are: Individual day traders, individual non-day traders, Foreign institutional traders, and Futures proprietary firm traders. 
Appendix A1: Daily limit and market order statistics by trader type categories

\begin{tabular}{|c|c|c|c|c|c|c|c|c|c|c|c|c|}
\hline \multirow[b]{2}{*}{ Time Interval } & \multicolumn{3}{|c|}{ Individual Day Traders } & \multicolumn{3}{|c|}{ Individual Non Day Traders } & \multicolumn{3}{|c|}{ Foreign Institutional Traders } & \multicolumn{3}{|c|}{ Futures Proprietary Firm Traders } \\
\hline & Limit & Market & $\begin{array}{c}\text { Limit Order } \\
\text { Submission } \\
\text { Ratio }(\%) \\
\end{array}$ & Limit & Market & $\begin{array}{c}\text { Limit Order } \\
\text { Submission } \\
\text { Ratio }(\%) \\
\end{array}$ & Limit & Market & $\begin{array}{c}\text { Limit Order } \\
\text { Submission } \\
\text { Ratio }(\%)\end{array}$ & Limit & Market & $\begin{array}{c}\text { Limit Order } \\
\text { Submission } \\
\text { Ratio }(\%)\end{array}$ \\
\hline $08: 30-08: 45^{\#}$ & 1103.57 & 122.29 & 0.9040 & 1473.78 & 365.73 & 0.8166 & 171.29 & 57.96 & 0.6702 & 459.20 & 56.03 & 0.8820 \\
\hline 1. 08:45-09:00 & 2424.71 & 654.19 & 0.7970 & 3231.79 & 1319.81 & 0.7210 & $2,501.52$ & 254.46 & 0.8901 & $3,018.86$ & 306.01 & 0.9013 \\
\hline 2. 09:00-09:15 & 3077.66 & 1102.94 & 0.7436 & 2779.15 & 1186.48 & 0.7059 & $3,831.26$ & 303.22 & 0.9088 & $3,579.10$ & 338.37 & 0.9014 \\
\hline 3. $09: 15-09: 30$ & 2936.30 & 1034.12 & 0.7504 & 2581.28 & 995.39 & 0.7272 & $3,835.20$ & 232.38 & 0.9223 & $3,302.74$ & 272.26 & 0.9112 \\
\hline 4. 09:30-09:45 & 2673.91 & 932.80 & 0.7533 & 2354.64 & 829.55 & 0.7448 & $3,523.15$ & 191.67 & 0.9271 & $3,021.31$ & 225.30 & 0.9138 \\
\hline 5. 09:45-10:00 & 2605.33 & 926.52 & 0.7521 & 2293.52 & 819.98 & 0.7431 & $3,292.02$ & 174.20 & 0.9246 & $2,861.99$ & 221.08 & 0.9174 \\
\hline 6. 10:00-10:15 & 2449.89 & 891.69 & 0.7479 & 2156.60 & 751.36 & 0.7505 & $3,040.37$ & 163.42 & 0.9231 & $2,657.30$ & 201.53 & 0.9206 \\
\hline 7. $10: 15-10: 30$ & 2337.75 & 855.79 & 0.7480 & 2044.19 & 691.99 & 0.7574 & $2,779.50$ & 146.13 & 0.9246 & $2,574.22$ & 185.44 & 0.9233 \\
\hline 8. $10: 30-10: 45$ & 2125.85 & 782.23 & 0.7484 & 1856.87 & 621.92 & 0.7594 & $2,650.45$ & 135.19 & 0.9298 & $2,466.49$ & 155.03 & 0.9307 \\
\hline 9. 10:45-11:00 & 2133.24 & 808.98 & 0.7451 & 1904.51 & 646.31 & 0.7600 & $2,642.69$ & 128.24 & 0.9312 & $2,545.49$ & 173.42 & 0.9283 \\
\hline 10. 11:00-11:15 & 2041.18 & 753.93 & 0.7483 & 1794.03 & 598.87 & 0.7634 & $2,486.67$ & 131.56 & 0.9249 & $2,391.45$ & 154.46 & 0.9300 \\
\hline 11. $11: 15-11: 30$ & 2147.25 & 815.82 & 0.7409 & 1911.18 & 667.99 & 0.7561 & $2,518.35$ & 139.41 & 0.9267 & $2,521.46$ & 180.56 & 0.9260 \\
\hline 12. $11: 30-11: 45$ & 2296.42 & 842.66 & 0.7471 & 1952.57 & 680.48 & 0.7555 & $2,673.03$ & 142.28 & 0.9269 & $2,624.35$ & 184.31 & 0.9249 \\
\hline 13. $11: 45-12: 00$ & 2267.86 & 848.34 & 0.7432 & 1943.20 & 698.52 & 0.7489 & $2,784.56$ & 137.32 & 0.9280 & $2,578.61$ & 183.63 & 0.9276 \\
\hline 14. $12: 00-12: 15$ & 2205.42 & 820.64 & 0.7481 & 1824.77 & 665.45 & 0.7516 & $2,882.34$ & 136.79 & 0.9301 & $2,517.69$ & 176.39 & 0.9301 \\
\hline 15. $12: 15-12: 30$ & 2288.94 & 833.51 & 0.7506 & 1963.87 & 707.18 & 0.7533 & $2,942.31$ & 148.56 & 0.9256 & $2,624.47$ & 193.42 & 0.9251 \\
\hline 16. $12: 30-12: 45$ & 2219.47 & 802.21 & 0.7528 & 1916.44 & 666.70 & 0.7548 & $2,830.23$ & 132.70 & 0.9331 & $2,602.55$ & 173.64 & 0.9274 \\
\hline 17. $12: 45-13: 00$ & 2310.13 & 813.67 & 0.7529 & 2034.33 & 723.50 & 0.7474 & $2,924.13$ & 137.78 & 0.9305 & $2,649.82$ & 190.02 & 0.9236 \\
\hline 18. $13: 00-13: 15$ & 2369.42 & 837.12 & 0.7539 & 2161.32 & 781.13 & 0.7459 & $3,162.03$ & 184.32 & 0.9205 & $2,738.87$ & 209.08 & 0.9185 \\
\hline 19. $13: 15-13: 30$ & 1938.85 & 642.16 & 0.7617 & 2040.39 & 722.36 & 0.7495 & $3,054.15$ & 245.83 & 0.9015 & $2,378.79$ & 171.61 & 0.9249 \\
\hline 20. $13: 30-13: 45$ & 1764.52 & 825.32 & 0.6753 & 2500.26 & 1243.20 & 0.6667 & $2,277.69$ & 349.67 & 0.8397 & $2,800.64$ & 359.67 & 0.8645 \\
\hline
\end{tabular}

Note: This table presents daily means of limit orders, market orders and limit order submission ratios during 15 minutes interval for Individual day traders, Individual non- day traders, foreign institutional traders, and Futures proprietary firm traders of the futures contract FITX. The Limit column is defined as the mean of limit orders sum during the 15-minute intraday interval. The Market column is defined as the mean of market orders, which is the sum of pure market orders and marketable limit orders, sum during the 15-minute intraday interval. The Limit Order Submission Ratio is defined as the means of the ratio of the limit orders to the sum of the limit, market orders during the 15-mintue intraday interval. " denotes the pre-open trading period from 8:30 AM to 8:45AM for each trading day. 
Appendix A2: Limit and market order size statistics by trader type categories

\begin{tabular}{|c|c|c|c|c|c|c|c|c|}
\hline \multirow[t]{2}{*}{ Time Interval } & \multicolumn{2}{|c|}{ Individual Day Trader } & \multicolumn{2}{|c|}{$\begin{array}{l}\text { Individual Non } \\
\text { Day Trader }\end{array}$} & \multicolumn{2}{|c|}{$\begin{array}{c}\text { Foreign Institutional } \\
\text { Traders } \\
\end{array}$} & \multicolumn{2}{|c|}{$\begin{array}{c}\text { Futures Proprietary Firm } \\
\text { Traders }\end{array}$} \\
\hline & Limit & Market & Limit & Market & Limit & Market & Limit & Market \\
\hline $08: 30-08: 45^{\#}$ & 2.16 & 2.00 & 2.68 & 2.49 & 11.14 & 31.48 & 5.94 & 7.38 \\
\hline 1. 08:45-09:00 & 2.24 & 1.83 & 2.39 & 2.19 & 5.49 & 8.57 & 2.87 & 4.35 \\
\hline 2. 09:00-09:15 & 2.42 & 2.02 & 2.39 & 2.28 & 5.03 & 6.69 & 2.58 & 3.89 \\
\hline 3. $09: 15-09: 30$ & 2.32 & 2.00 & 2.38 & 2.30 & 5.09 & 6.03 & 2.51 & 4.09 \\
\hline 4. $09: 30-09: 45$ & 2.29 & 1.98 & 2.41 & 2.30 & 5.15 & 6.14 & 2.49 & 4.13 \\
\hline 5. 09:45-10:00 & 2.29 & 1.98 & 2.46 & 2.34 & 5.08 & 5.95 & 2.46 & 4.21 \\
\hline 6. $10: 00-10: 15$ & 2.24 & 1.97 & 2.48 & 2.35 & 5.11 & 5.89 & 2.39 & 4.19 \\
\hline 7. $10: 15-10: 30$ & 2.22 & 1.96 & 2.47 & 2.34 & 5.05 & 5.51 & 2.38 & 4.04 \\
\hline 8. $10: 30-10: 45$ & 2.15 & 1.93 & 2.42 & 2.35 & 4.83 & 5.47 & 2.37 & 3.99 \\
\hline 9. 10:45-11:00 & 2.13 & 1.96 & 2.47 & 2.35 & 4.91 & 5.23 & 2.41 & 4.18 \\
\hline 10. 11:00-11:15 & 2.16 & 1.97 & 2.48 & 2.37 & 4.89 & 5.57 & 2.40 & 4.09 \\
\hline 11. $11: 15-11: 30$ & 2.19 & 1.99 & 2.51 & 2.40 & 4.89 & 5.18 & 2.40 & 4.07 \\
\hline 12. $11: 30-11: 45$ & 2.26 & 2.00 & 2.50 & 2.40 & 4.99 & 5.31 & 2.43 & 3.54 \\
\hline 13. 11:45-12:00 & 2.25 & 2.02 & 2.45 & 2.41 & 5.11 & 5.08 & 2.40 & 3.84 \\
\hline 14. $12: 00-12: 15$ & 2.29 & 2.04 & 2.42 & 2.39 & 5.18 & 5.04 & 2.35 & 4.05 \\
\hline 15. $12: 15-12: 30$ & 2.33 & 2.04 & 2.50 & 2.40 & 5.22 & 4.87 & 2.37 & 4.22 \\
\hline 16. $12: 30-12: 45$ & 2.34 & 2.04 & 2.50 & 2.37 & 5.15 & 4.80 & 2.43 & 4.08 \\
\hline 17. $12: 45-13: 00$ & 2.37 & 2.05 & 2.51 & 2.40 & 5.14 & 4.74 & 2.42 & 4.19 \\
\hline 18. 13:00-13:15 & 2.41 & 2.05 & 2.52 & 2.39 & 5.24 & 4.47 & 2.42 & 4.18 \\
\hline 19. $13: 15-13: 30$ & 2.39 & 2.00 & 2.53 & 2.35 & 5.44 & 4.93 & 2.41 & 4.20 \\
\hline 20. $13: 30-13: 45$ & 2.42 & 2.00 & 2.60 & 2.36 & 5.61 & 7.18 & 2.80 & 4.16 \\
\hline
\end{tabular}

traders, foreign institutional traders, and futures proprietary firm traders respectively. The Limit column is defined as the mean of limit order during the 15-minute $y$ interval. The Market column is defined as the mean of market orders, which is the sum of pure market orders and marketable limit orders, during the 15-minute interval. " denotes the time from 8:30 AM to 8:45AM is a pre-open trading period for each trading day. 